\title{
Metal-Free $\alpha$-Amination of Secondary Amines: Computational and Experimental Evidence for Azaquinone Methide and Azomethine Ylide Intermediates
}

\author{
Arne Dieckmann, ${ }^{\dagger}$ Matthew T. Richers, ${ }^{\ddagger}$ Alena Yu. Platonova, ${ }^{\ddagger}{ }^{\ddagger}$ Chen Zhang, ${ }^{\ddagger}$ Daniel Seidel, ${ }^{\ddagger} *$
} and K. N. Houk ${ }^{* \dagger}$

${ }^{\dagger}$ Department of Chemistry and Biochemistry, University of California, Los Angeles, California 90095, United States

${ }^{\ddagger}$ Department of Chemistry and Chemical Biology, Rutgers, The State University of New Jersey, Piscataway, New Jersey 08854, United States

${ }^{\S}$ Department of Organic Synthesis Technology, Ural Federal University, Yekaterinburg, 620002, Russia

\section{Supporting Information}

ABSTRACT: We have performed a combined computational and experimental study to elucidate the mechanism of a metal-free $\alpha$-amination of secondary amines. Calculations predicted azaquinone methides and azomethine ylides as the reactive intermediates and showed that iminium ions are unlikely to participate in these transformations. These results were confirmed by experimental deuterium-labeling studies and the successful trapping of the postulated azomethine ylide and azaquinone methide intermediates. In addition, computed barrier heights for the rate-limiting step correlate qualitatively with experimental findings.

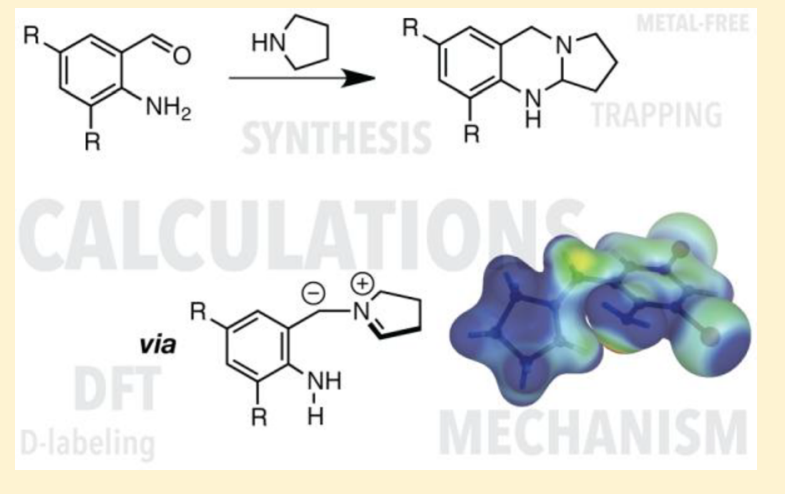

\section{INTRODUCTION}

Aminal substructures ${ }^{1}$ are present in a number of natural products, ${ }^{2}$ which makes simple synthetic procedures to their precursors and analogues important to the organic chemist. Recently, one of our groups developed an efficient route to ring-fused aminals ${ }^{3,4}$ by metal-free, redox-neutral ${ }^{5} \mathrm{C}-\mathrm{H}$ functionalization of cyclic amines (Scheme 1). ${ }^{6,7}$ The procedure is straightforward and only requires heating an aminobenzaldehyde with an excess of amine in ethanol to afford the aminal in one step. Most methods that involve the functionalization of relatively nonreactive $\mathrm{C}-\mathrm{H}$ bonds require the use of transition-metal catalysts, often in combination with (super)stoichiometric amounts of oxidant. ${ }^{8}$ Here, we report the results of a computational and experimental study aimed at delineating the mechanistic pathways of this practical and convenient transformation. The mechanism was predicted by an extensive exploration of possible pathways using density functional theory (DFT) calculations based on the original experimental results ${ }^{3,4}$ and is in line with subsequently performed deuterium-labeling and trapping experiments.

Some of the key findings of the initial investigation are summarized in eqs $1-4$. The scope of the aminal formation includes different cyclic secondary amines and electrondeficient $o$-aminobenzaldehydes were found to work best. Interestingly, not only the electronic structure, but also the geometry of the amines, has a profound effect on reactivities and yields. Pyrrolidine gives excellent yields with electron-poor aminobenzaldehydes such as 1a (eq 1). Good yields can also be obtained with more electron-rich aminobenzaldehydes (e.g., 1b), although extended reaction times are required. Even with the highly reactive aminobenzaldehyde $\mathbf{1 a}$, piperidine requires prolonged reaction times at elevated temperatures and the yield drops significantly (eq 2). Morpholine is even less reactive. Cyclic amines with benzylic $\alpha-\mathrm{C}-\mathrm{H}$ bonds such as $1,2,3,4-$ tetrahydroisoquinoline (THIQ) are excellent substrates (eq 3 ). In contrast, no product could be obtained with 1,2,3,4tetrahydroquinoline (THQ) under a variety of conditions (eq 4).

Various potential mechanisms have been considered for these transformations, all of which are in line with experimental conditions. Using the reaction of $\mathbf{1} \mathbf{b}$ and pyrrolidine as a prototypical example, a number of potential mechanistic pathways are summarized in Scheme 1. All start with the formation of hemiaminal $\mathbf{3 b}$ that should be formed rapidly upon mixing of the aldehyde and amine. Afterward, $\mathbf{3 b}$ can eliminate hydroxide to form iminium ion $\mathbf{4} \mathbf{b}$, which can undergo a variety of reactions. Deprotonation by an external base either leads to $o$-aza-quinone methide $5 b^{9}$ or azomethine ylide $\mathbf{6 b} .^{10,11}$ Aza-quinone methide $\mathbf{5 b}$ can also be obtained by a direct dehydration of hemiaminal $\mathbf{3 b}$ (vide infra). Alternatively, the protonated azomethine ylide $10 \mathrm{~b}$ can be formed by an internal proton transfer ${ }^{12}$ and is likely to undergo another

Received: March 18, 2013

Published: March 21, 2013 


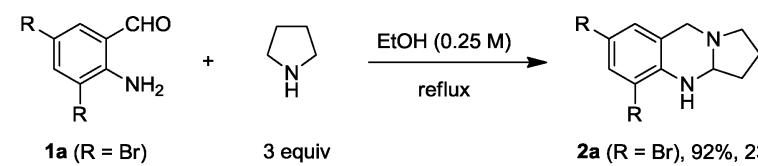

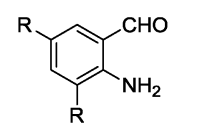

1a $(\mathrm{R}=\mathrm{Br})$ $1 b(R=H)$ $\begin{array}{lll}\text { 1a }(R=B r) & 3 \text { equiv } & \text { 2a }(R=B r), 92 \%, 23 h \\ \text { 1b }(R=H) & 2 b(R=H), 73 \%, 72 h\end{array}$

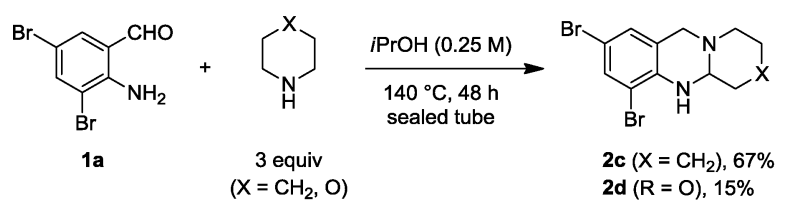

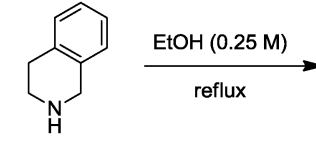

3 equiv

Regioisomers not observed

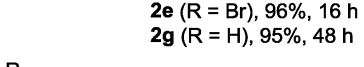

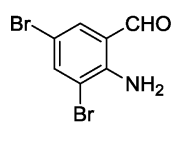

$+$

1a
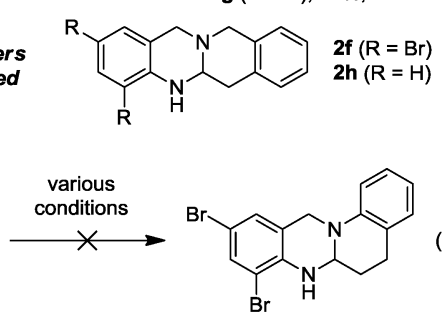

2i (not observed) proton transfer resulting in iminium species $\mathbf{8 b}$. In addition to the rather unlikely pathway involving $\mathbf{1 0 b}$ as an intermediate, iminium ion $\mathbf{8 b}$ can be obtained from $\mathbf{5 b}$ via azomethine ylide $\mathbf{6 b}$. The latter could be formed from $\mathbf{5} \mathbf{b}$ either by a 1,6-hydride shift $^{13}$ or a 1,6-proton transfer. ${ }^{12}$ Subsequent protonation of azomethine ylide $\mathbf{6 b}$, e.g., by solvent molecules, results in $\mathbf{8 b}$. The ring closure can either proceed via iminium ion $\mathbf{8 b}$ or zwitterion $7 \mathbf{b}$. An intramolecular attack of the amino group nitrogen on the iminium moiety in $\mathbf{8 b}$ leads to the protonated product $\mathbf{9 b}$, while the formation of $7 \mathbf{b}$ by a (solvent-mediated) proton transfer and a subsequent intramolecular attack leads to the neutral product $\mathbf{2 b}$. The direct transformation of $\mathbf{4 b}$ to $\mathbf{8 b}$ via 1,3 -hydride shift was not considered. ${ }^{14}$

Overall, there are several plausible and interconnected mechanisms leading to products 2 that differ with respect to the intermediates involved and their protonation states. As a consequence, a purely experimental mechanistic elucidation of this reaction is likely to be extremely challenging. In order to discriminate between the different mechanistic possibilities, we undertook a detailed computational study based on DFT and arrived at a consistent, but partly unexpected mechanism. In addition, new experimental data were obtained on selectivities and reactivities of different substrates, and deuterium-labeling studies were performed that provide evidence that supports the computational results. Further support was obtained by trapping of an azomethine ylide and an azaquinone methide.

For the sake of clarity, we will first provide our new experimental results. Afterward, we will discuss our calculations and rationalize the experimental findings based on the predicted mechanism.

\section{EXPERIMENTAL RESULTS AND DISCUSSION}

Evidence for the Intermediacy of Azaquinone Methides. In order to support or rule out the mechanistic pathways presented in Scheme 1, we designed a number of experiments with the goal to trap some of the proposed intermediates, in particular $o$-azaquinone methides (e.g., 5b) and azomethine ylides (e.g., 6b). After a series of failed attempts to trap the proposed quinoidal intermediates via intermolecular hetero-Diels-Alder reactions, we explored the possibility of tethering a dienophile to one of the reactants. To this end, we prepared aminobenzaldehyde 11 bearing an $\alpha, \beta$ unsaturated ester attached to nitrogen via a four-carbon alkyl chain linker (Scheme 2). Upon exposure of 11 to standard aminal forming conditions with excess pyrrolidine, we recovered compound 12 in $7 \%$ yield, the apparent product of an endoselective hetero-Diels-Alder reaction (see structure 17). Another product that was isolated from the reaction mixture is compound 13 (7\%), possibly formed upon elimination of pyrrolidine from compound 12. In addition, we obtained conjugate addition product 14 (42\%), aminal $15(20 \%),{ }^{15}$ and recovered starting material 11 (9\%). While these results are consistent with an $o$-azaquinone methide intermediate, we needed to rule out alternative reaction pathways for the formation of $\mathbf{1 2}$ that do not involve a $[4+2]$ cycloaddition.

Potentially, tricycle 13 could be formed directly in a BaylisHillman-like reaction, ${ }^{16}$ and a conjugate addition of pyrrolidine to 13 could result in the formation of apparent Diels-Alder product 12 . We tested for this possibility in a series of experiments (Scheme 2). Heating 11 in the absence of any additives did not lead to formation of 13. Since pyrrolidine could simply act as a base to catalyze cyclization of tethered alkene $\mathbf{1 1}$ to yield cyclization product product 13, we also performed the reaction in the presence of Hünig's base (similar $\mathrm{p} K_{\mathrm{aH}}$ to pyrrolidine) and $\mathrm{N}$-methylpyrrolidine. No reaction was observed in either case, and starting material 11

Scheme 1. Potential Mechanistic Pathways for the Redox-Neutral Aminal Formation. Blue Arrows Refer to the Lowest Energy Pathway as Elucidated by DFT Calculations

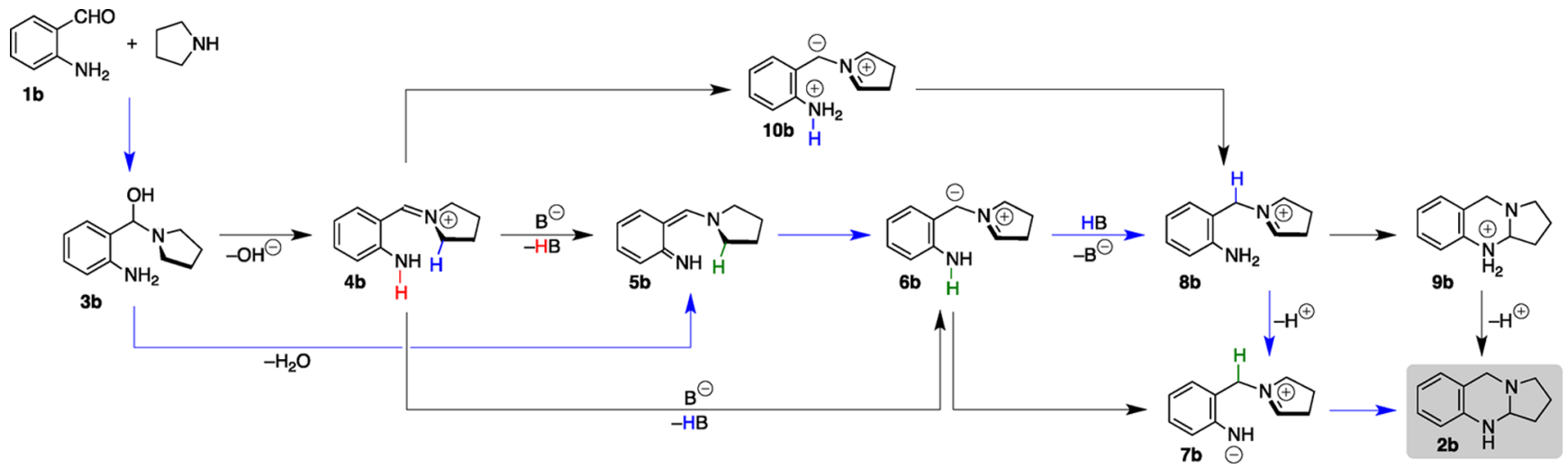


Scheme 2. Capture of an o-Azaquinone Methide Intermediate via Intramolecular $[4+2]$ Cycloaddition and Relevant Control Experiments
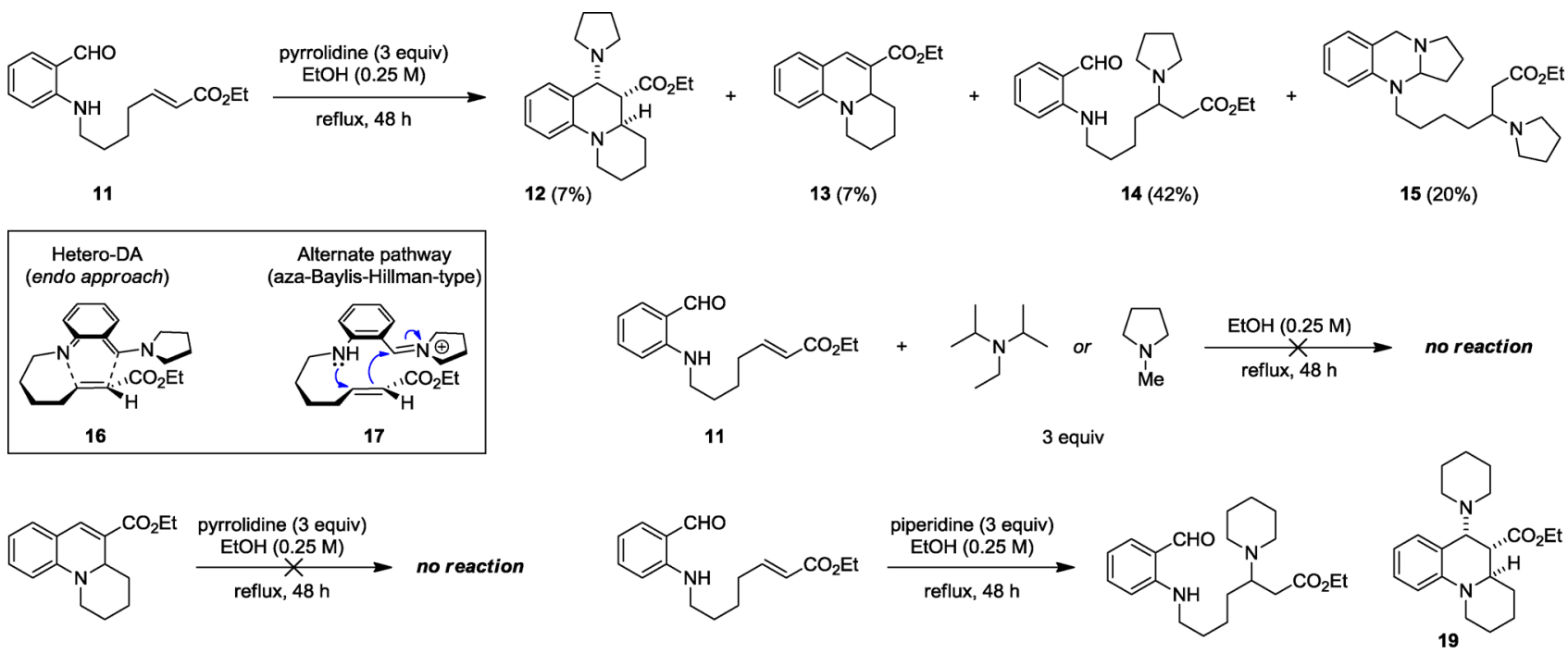

was recovered quantitatively. Furthermore, to ensure that the apparent Diels-Alder product $\mathbf{1 2}$ is not the product of conjugate addition of pyrrolidine to tricycle 13, the latter was exposed to pyrrolidine in refluxing ethanol for $48 \mathrm{~h}$. No reaction was observed in this instance. This strongly suggests that $\mathbf{1 2}$ is not a conjugate addition product, but rather that $\mathbf{1 3}$ results from the elimination of pyrrolidine from $\mathbf{1 2}$.

An aza-Baylis-Hillman-type pathway ${ }^{16}$ (e.g., structure 17 in Scheme 2) would also account for the formation of $\mathbf{1 2}$. However, given the unlikeliness of iminium ion formation under the reaction conditions (see the Computational Results), this pathway was not considered further. Interestingly, the analogous reaction of 11 with piperidine only led to conjugate addition product 18 in $47 \%$ yield, in addition to recovered starting material. The lack of formation of 19 or the corresponding aminal product can be attributed to an increased difficulty of accessing the required ortho-azaquinone methide or azomethine ylide intermediates. Another possible pathway, namely pyrrolidine acting as a nucleophilic Lewis base catalyst in an intramolecular Baylis-Hillman reaction was ruled out on the basis that this would require the formation of an intermediate with a 10-membered ring (not shown).

Evidence for the Intermediacy of Azomethine Ylides. Aldehydes are known to act as potent dipolarophiles in reactions with azomethine ylides. ${ }^{17}$ In cases where azomethine ylides are formed from amino acids and aldehydes in the presence of other dipolarophiles, these cycloadditions can become unintended side reactions. We decided to exploit this reactivity pattern to establish the intermediacy of azomethine ylides in the aminal formation. In order to promote intermolecular [3+2] cycloaddition and hopefully suppress aminal formation, pyrrolidine was allowed to react with 2 equiv of aminobenzaldehyde 1a (eq 5). The reaction was performed in ethanol solution 4-fold more concentrated than under

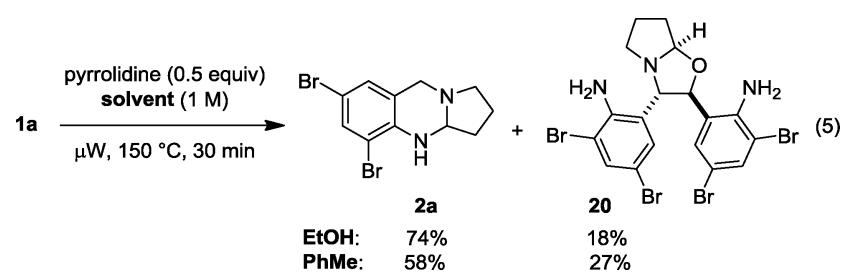

standard conditions. A microwave reactor was used to facilitate product formation. Following a reaction time of $30 \mathrm{~min}$ at $150{ }^{\circ} \mathrm{C}$, cycloaddition product $\mathbf{2 0}$ was isolated in $18 \%$ yield along with aminal 2a (74\%). When toluene was used as the solvent under otherwise identical conditions, the yield of the $[3+2]$ product 20 increased to $27 \%$, while aminal $2 \mathrm{a}$ was recovered in $58 \%$ yield. This increase in yield in an apolar solvent is consistent with a reduced quantity of proton sources available to protonate the azomethine ylide. In both solvents, $\mathbf{2 0}$ was obtained as a single diastereomer. The relative stereochemistry of $\mathbf{2 0}$ matches that of the major products previously reported in analogous $[3+2]$ reactions. ${ }^{17}$ These observations strongly support the intermediacy of an azomethine ylide.

Deuterium-Labeling Studies. A number of deuteriumlabeling experiments were performed in order to obtain further insights into the mechanism of the aminal formation. When a reaction of aminobenzaldehyde 1a and pyrrolidine was conducted in EtOD, aminal 2a was obtained with close to $100 \%$ incorporation of one deuterium atom, distributed approximately equally over the two diastereotopic benzylic protons (eq 6). ${ }^{18}$ To confirm that deuteration occurred during aminal formation, nondeuterated $2 \mathrm{a}$ was exposed to identical reaction conditions (reflux in EtOD for $48 \mathrm{~h}$ in the presence of 2 equiv of pyrrolidine). No trace of deuterium incorporation was observed in this case. These results are consistent with an azomethine ylide intermediate related to $\mathbf{6} \mathbf{b}$ being protonated by solvent to form an iminium ion of type $\mathbf{8 b}$. The corresponding experiment was also performed with THIQ (eq 7). Interestingly, in this case partial deuterium incorporation was observed for all three benzylic protons with a total deuterium incorporation of $\sim 100 \%$. The observation of deuterium incorporation at the aminal carbon likely reflects a difference in charge distributions of the azomethine ylides derived from pyrrolidine vs THIQ. ${ }^{19}$ However, the fact that substantially less than one deuterium atom was incorporated into the two diastereotopic benzylic positions of the dibromoaniline ring seemed at odds with the proposed mechanism. One possible explanation would be that the protonation step exhibits a relatively large kinetic isotope effect. The two starting materials could serve as a source of protons. In order to minimize the total number of protons available in the system, we repeated this experiment with substrates in which the exchangeable protons had been replaced with deuterium (eq 8). Indeed, in the event, 


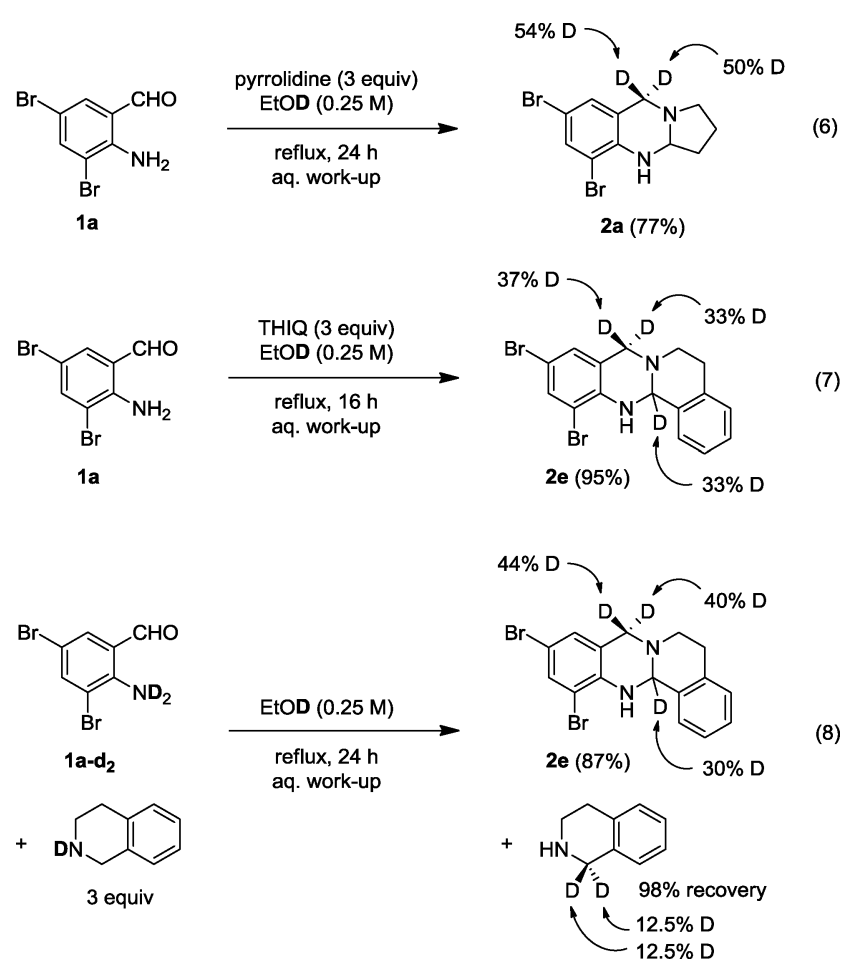

substantially increased deuterium incorporation was observed in the benzylic position of the dibromoaniline ring. Interestingly, the recovered THIQ was found to be partially deuterated, indicating the reversibility of the early reaction steps. Deuteration of the benzylic position of THIQ requires the presence of $1 \mathrm{a}$ (i.e., heating of THIQ in EtOD under reflux for $16 \mathrm{~h}$ did not lead to any incorporation of deuterium into the benzylic position of THIQ).

Deuterium labeling experiments were also used to potentially gain some insights into the nature of the rate-limiting step of the reaction by measuring the kinetic isotope effect (KIE). As the relatively long reaction times and high temperatures required for aminal formation would make spectroscopic monitoring of the progress rather difficult, we chose to measure isotope effects with $P_{\mathrm{H}} / P_{\mathrm{D}}$ values from competition experiments rather than determining $K_{\mathrm{H}} / K_{\mathrm{D}}$ from reaction rates. ${ }^{20}$ A reaction of aminobenzaldehyde $1 \mathrm{a}$ and pyrrolidine was conducted in a 1:1 mixture of EtOH and EtOD (eq 9). A $P_{\mathrm{H}} / P_{\mathrm{D}}$ value of 2.1 was observed, which would be
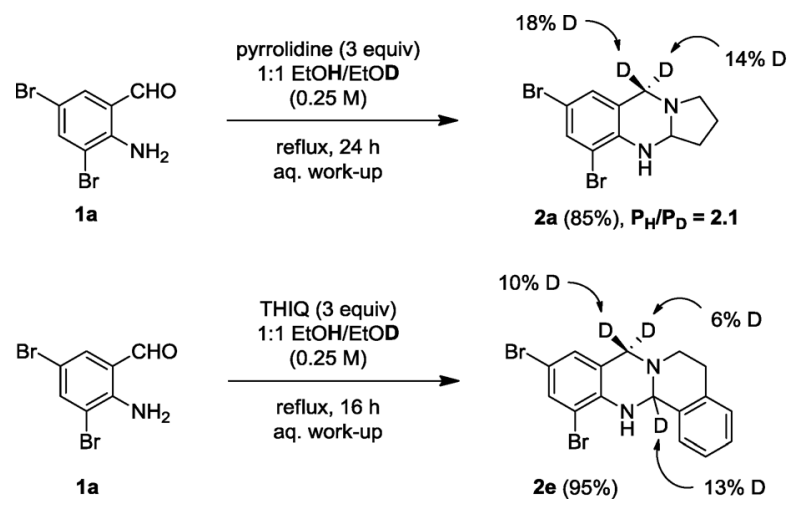

consistent with the protonation step being rate determining. A similar outcome was observed in the corresponding experiment with THIQ (eq 10). However, calculation of a meaningful $P_{\mathrm{H}} / P_{\mathrm{D}}$ value is complicated by the above-mentioned complexities (see eqs 7 and 8). Regardless, there appears to be a substantial KIE. ${ }^{21}$
The relative rates of $\mathrm{C}-\mathrm{H}$ vs $\mathrm{C}-\mathrm{D}$ functionalization were probed with partially deuterated amine substrates (eqs 11-13). A reaction
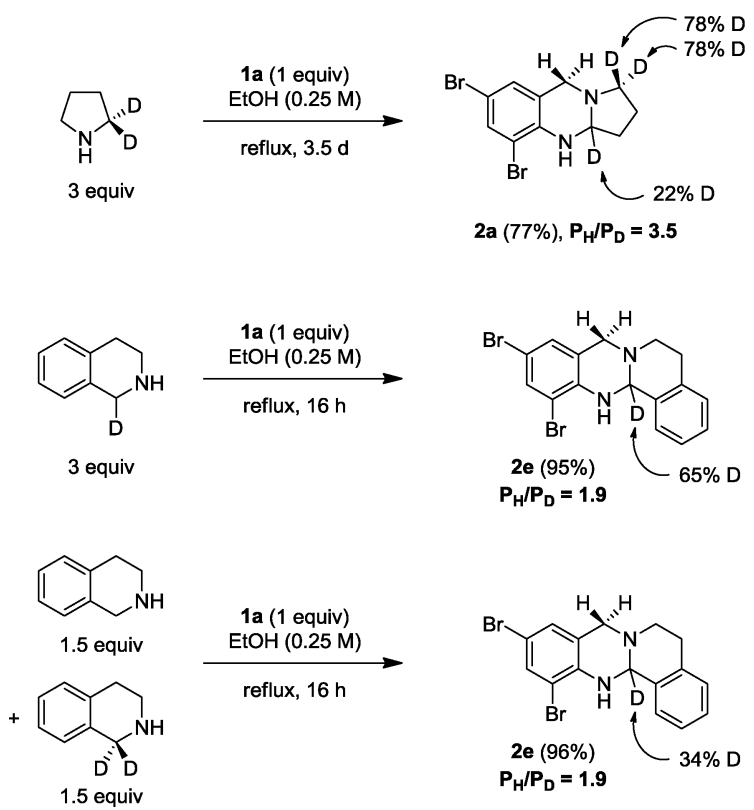

of pyrrolidine-2,2- $d_{2}$ with 1 a resulted in the formation of partially deuterated $2 \mathrm{a}$ in $77 \%$ yield (eq 11 ). The observed $P_{\mathrm{H}} / P_{\mathrm{D}}$ value of 3.5 is consistent with the $\mathrm{C}-\mathrm{H}$ functionalization step being rate determining. A substantially lower $P_{\mathrm{H}} / P_{\mathrm{D}}$ value of 1.9 was observed in the corresponding reaction with THIQ-1-d (eq 12). A related competition experiment with a 1:1 mixture of THIQ and THIQ$1,1-d_{2}$ also gave rise to a $P_{\mathrm{H}} / P_{\mathrm{D}}$ value of 1.9 (eq 13). The experiments in eqs 11-13 conclusively rule out the intervention of a 1,3-hydride shift, as no measurable amount of deuterium was incorporated into the benzylic position of the dibromoaniline ring. Overall, the isotopic labeling experiments outlined in eqs 6-13 do not rule out azomethine ylide protonation or $\mathrm{C}-\mathrm{H}$ functionalization as the rate limiting step.

Regioselectivity of the Aminal Formation for Nonsymmetrical Amines. Insights into the mechanism of the aminal formation may also be obtained from nonsymmetrical amines that could, at least in principle, give rise to different regioisomeric products. As shown previously, the reaction of THIQ and aminobenzaldehyde $\mathbf{1 b}$ under standard conditions gave rise to product $2 \mathrm{~g}$ in high yield, resulting from exclusive functionalization of a benzylic $\mathrm{C}-\mathrm{H}$ bond (eq 3). This outcome is entirely anticipated on the basis of the generally observed greater reactivity of benzylic over aliphatic $\mathrm{C}-\mathrm{H}$ bonds. We were thus surprised to observe trace amounts of regioisomeric product $2 \mathrm{~h}$ when this reaction was first conducted under microwave conditions with the initial goal of simply enhancing the reaction rate. Closer inspection revealed that substantial amounts of product $\mathbf{2 h}$ can be obtained at higher temperatures (eq 14). Specifically, a reaction of $\mathbf{1 b}$ and THIQ conducted under microwave irradiation at $250{ }^{\circ} \mathrm{C}$ for $30 \mathrm{~min}$, gave rise to $\mathbf{2 h}$ in $16 \%$ yield in addition to the expected product $\mathbf{2 g}$ which was isolated in $72 \%$ yield. Moreover, extending the reaction time from $30 \mathrm{~min}$ to $2 \mathrm{~h}$ led to the formation of $2 \mathbf{h}$ as the major product in $47 \%$ yield, without significantly affecting the combined yield of $\mathbf{2 g}$ and $2 \mathrm{~h}$. These observations suggest that aminal $2 \mathrm{~g}$ is in fact the kinetic product of this transformation whereas $2 \mathrm{~h}$ represents the thermodynamically more stable aminal product. Furthermore, there appears to be a pathway for product isomerization. Prompted by this discovery, we decided to investigate the reaction of 


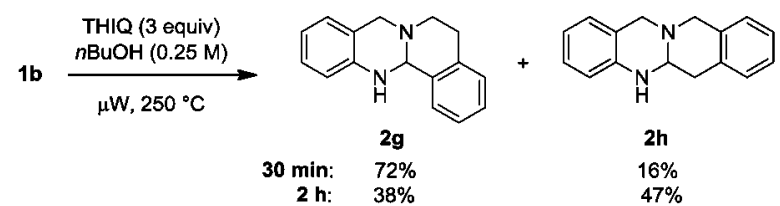

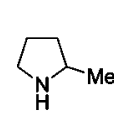

3 equiv
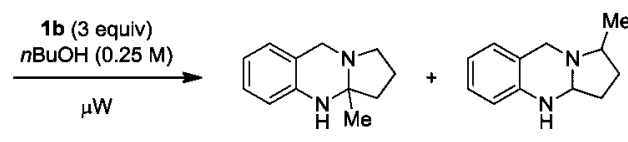

2)

$180^{\circ} \mathrm{C}, 1.5 \mathrm{~h}: 76 \%(2.4: 1)$

$250^{\circ} \mathrm{C}, 15 \mathrm{~min}: 92 \%(2.6: 1)$ 2-methylpyrrolidine with aminobenzaldehyde $\mathbf{1 b}$ (eq 15). Interestingly, for this particular substrate combination, virtually identical product ratios were obtained under a variety of conditions. Aminal $\mathbf{2 j}$ was consistently obtained as the major product, illustrating the preferential functionalization of a tertiary over a secondary $\mathrm{C}-\mathrm{H}$ bond. These results are consistent with our previous findings in a reaction of 2-methylpyrrolidine with 1 a which was conducted under reflux ${ }^{3 a}$

\section{COMPUTATIONAL METHODS}

Geometry optimizations were performed with the meta-hybrid density functional M06-2X $\mathrm{X}^{22}$ and a $6-31+\mathrm{G}(\mathrm{d}, \mathrm{p})$ basis set. Solvation by ethanol was taken into account by the SMD solvent model, ${ }^{23}$ which was applied to both optimizations as well as frequency calculations. It was recently shown that the presence of a polarizable continuum model does not have a great impact on frequencies, while it might be mandatory to locate certain transition states that only exist in polar media. ${ }^{24}$ Thermal corrections were calculated from unscaled harmonic vibrational frequencies at the same level of theory for a standard state of $1 \mathrm{~mol} \mathrm{~L}^{-1}\left(17.12 \mathrm{~mol} \mathrm{~L}^{-1}\right.$ for ethanol) and $298.15 \mathrm{~K}$, as the experimental conditions of refluxing ethanol and high pressure in sealed tubes cannot be reproduced. The resulting free energies refer to Gibbs free energies. Free energies as well as enthalpies are corrected for zero-point vibrational energy. All stationary points were characterized and confirmed by vibrational analysis. An ultrafine grid corresponding to 99 radial shells and 590 angular points was used throughout this study for numerical integration of the density. Natural population analyses ${ }^{25}$ used the NBO program (version 3.1) as implemented in Gaussian 09. All calculations were performed with Gaussian $09{ }^{26}$

\section{COMPUTATIONAL RESULTS AND DISCUSSION}

General Mechanism. At the outset of our computational study we considered all mechanisms depicted in Scheme 1. In the following, the mechanism that was predicted to be the most favorable is discussed with the prototypic reaction of amino aldehyde $\mathbf{1 b}$ and pyrrolidine (Scheme 3 ). A matching free energy profile is shown in Figure 2.

The first step in the reaction cascade is the formation of hemiaminal $\mathbf{3 b} \mathbf{b}$, which is exothermic but endergonic according to our calculations. To obtain an iminium ion as suggested in Scheme 1, hydroxide needs to be eliminated. Upon elimination, hydroxide spontaneously abstracts the amine hydrogen leading to a set of two quinoidal intermediates, cis-5b and trans-5b (Figure 1). We could also locate transition states trans-TS-3b and cis-TS-3b, directly connecting hemiaminal $3 \mathbf{b}$ with trans$\mathbf{5 b}$ and $\mathbf{c i s}-\mathbf{5 b}$ by a concerted elimination of water (Scheme 3 and Figure 2). Both transition states are lower in terms of enthalpy and free energy than the corresponding iminium ion, suggesting that trans-5b and cis-5b are formed directly from $3 \mathbf{b}$
Scheme 3. General Mechanism for the $\alpha$-Amination of Nitrogen Heterocycles Is Exemplified with the Prototypic Reaction of $1 \mathrm{~b}$ and Pyrrolidine Leading to Product $2 \mathrm{~b}$
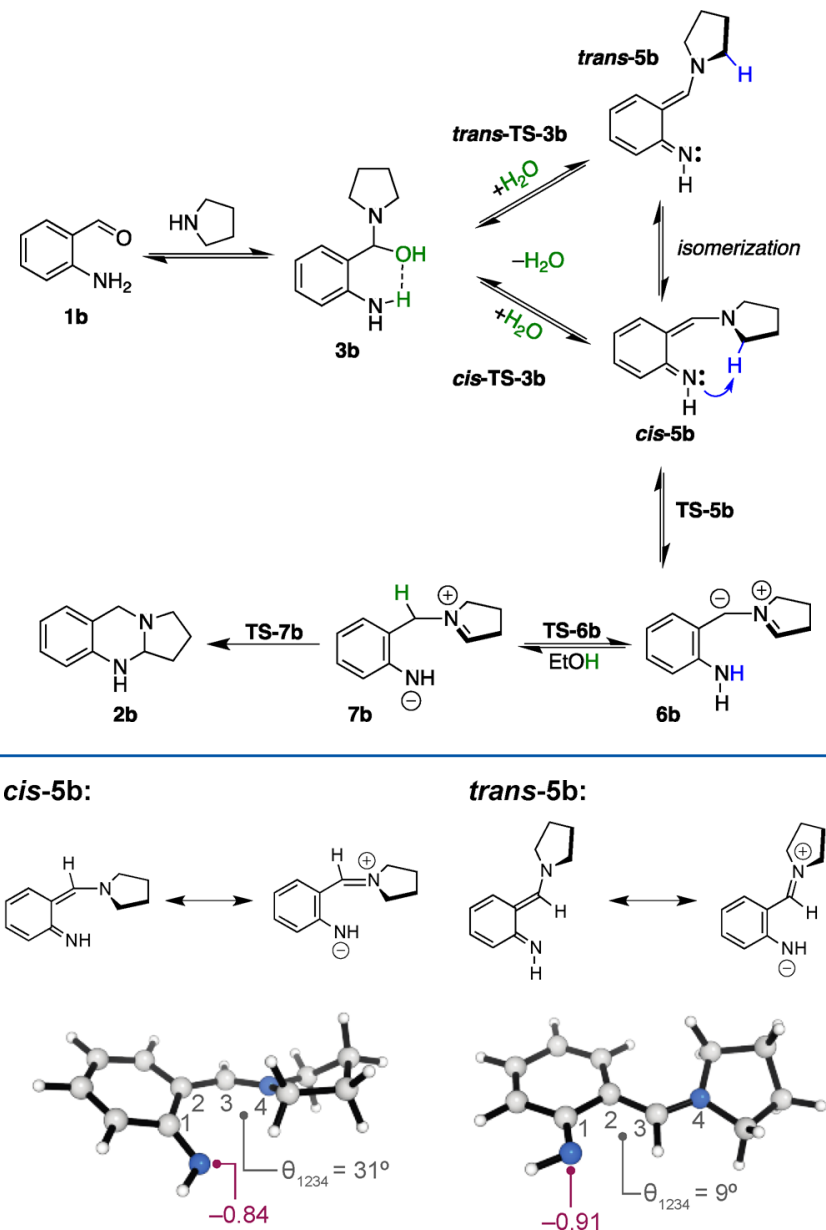

trans-5b:

Figure 1. Structures of quinoidal intermediates cis-5b and trans-5b. Charges for nitrogen atoms were obtained from a natural population analysis. The dihedral angle $\theta$ is a measure for the planarity of the exocyclic $\pi$-system ( $0^{\circ}$ corresponds to a perfectly flat geometry).

and not via iminium species $\mathbf{4 b}$ as assumed before (Scheme 2 ). As a consequence, pathways involving the iminium ion do not warrant further consideration.

It must be noted that computed enthalpies and as a consequence free energies are overestimated particularly for TS-3b, as this transition state benefits greatly from hydrogen bonding of solvent molecules to the leaving water molecule. As a consequence, we consider TS-3b $\left(24.7 \mathrm{kcal} \mathrm{mol}^{-1}\right)$ to be always lower in enthalpy and free energy than TS-5b (15.9/ $16.9 \mathrm{kcal} \mathrm{mol}^{-1}$ ), which is in perfect agreement with experimental data.

trans-TS-3b and cis-TS-3b differ with respect to the geometry of substituents at one exocyclic double bond. While cis-5b allows an abstraction of the $\alpha$-hydrogens of the heterocycle by the imine nitrogen via TS-5b, an intramolecular reaction is impossible in trans-5b. trans-TS-3b and trans-5b are $1 \mathrm{kcal} \mathrm{mol}^{-1}$ lower in energy than their corresponding cis-isomers due a greater planarity of the resulting exocyclic $\pi$-system (Figure 1), corresponding to a reduced $\mathrm{A}^{1,3}$-strain interaction.

A highly negative charge on the primary nitrogen obtained from a natural population analysis in $\mathbf{5 b}$ indicates a significant 


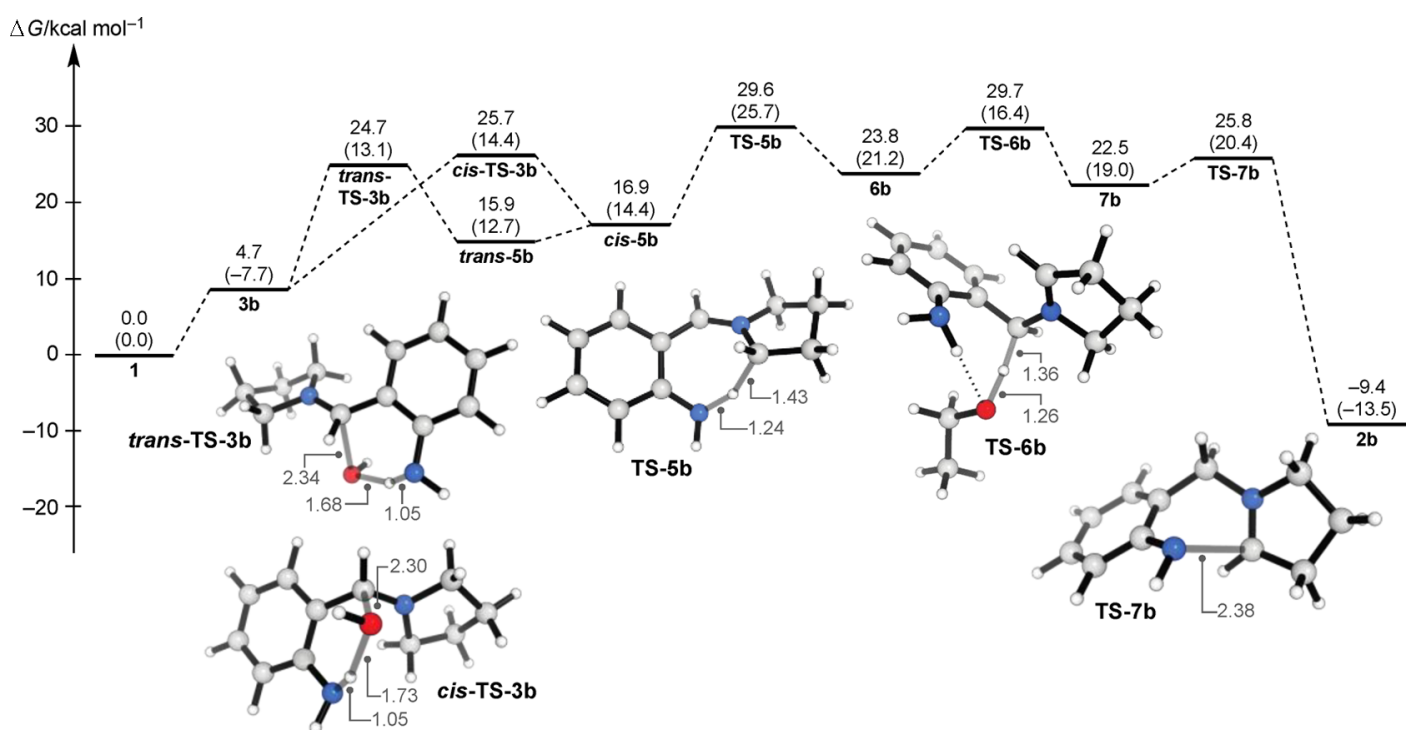

Figure 2. Gibbs free energy profile for the reaction depicted in Scheme 3. Free energies and enthalpies in parentheses are given in kcal mol ${ }^{-1}$ and bond lengths in $\AA$.

Table 1. Free Energies (And Enthalpies in Parentheses) $\left(\mathrm{kcal} \mathrm{mol}^{-1}\right)$ for All Intermediates and Transition States (M06-2X/ 6-31+G(d,p)/SMD(Ethanol $))$

\begin{tabular}{|c|c|c|c|c|c|c|c|c|c|c|c|}
\hline $\begin{array}{l}\text { product } \\
\qquad 2 x\end{array}$ & $3 x$ & trans-TS-3x & cis-TS-3x & trans $-\mathbf{5 x}$ & cis-5x & TS-5x & $6 x$ & TS-6x & $7 x$ & TS-7x & $2 x$ \\
\hline $\mathbf{a}$ & $3.4(-9.1)$ & $21.9(10.3)$ & $22.6(11.0)$ & $1.1(8.8)$ & $1.8(9.8)$ & $25.1(21.5)$ & $8.1(15.8)$ & $23.9(13.6)$ & $12.9(11.9)$ & $17.7(14.2)$ & $-8.6(-$ \\
\hline b & $4.7(-7.7)$ & $24.7(13.1)$ & $25.7(14.4)$ & $5.9(12.7)$ & $16.9(14.4)$ & $29.6(25.7)$ & $3.8(21.2)$ & $28.0(16.4)$ & $22.5(19.0)$ & $25.8(20.4)$ & $-9.4(-13.5)$ \\
\hline c & $2.9(-8.4)$ & $29.2(18.2)$ & $29.2(18.8)$ & & & $32.1(29.9)$ & $23.5(23.5)$ & & $15.9(14.9)$ & & \\
\hline d & $2.9(-8.0)$ & $31.4(20.0)$ & $30.8(20.4)$ & $(0)$ & $16.8(15.5)$ & 32.9 & $26.0(24.6)$ & & 21.4 & 19.0) & $(-7.8)$ \\
\hline e & $0.0(-11.4)$ & $25.3(16.2)$ & $25.5(16.6)$ & & $16.3(15.0)$ & $23.1(20.1)$ & $14.4(12.7)$ & $28.5(14.8)$ & & $15.7(12.3)$ & $-11.0(-15.9)$ \\
\hline f & $2.4(-10.7)$ & $25.5(16.5)$ & $24.2(16.7)$ & $16.2(14.1)$ & $17.4(15.3)$ & $29.8(26.2)$ & $23.3(21.3)$ & $32.2(18.0)$ & $16.4(16.0)$ & $19.7(16.0)$ & $-13.8(-17.9)$ \\
\hline g & $4.7(-7.3)$ & $30.6(19.2)$ & $31.5(20.2)$ & $20.3(18.7)$ & $21.2(19.6)$ & $27.5(24.1)$ & $19.0(16.9)$ & $29.1(19.1)$ & $22.7(20.7)$ & $24.1(20.4)$ & $-6.9(-11.0)$ \\
\hline h & $4.7(-7.3)$ & $30.6(19.4)$ & $31.4(20.2)$ & $20.7(19.2)$ & $22.3(20.0)$ & $33.9(30.5)$ & $28.9(26.9)$ & $32.8(23.2)$ & $25.7(24.0)$ & $27.6(24.2)$ & $-9.2(-13.4)$ \\
\hline i & $4.6(-6.7)$ & $32.2(21.4)$ & $34.1(22.6)$ & $20.1(17.1)$ & $21.1(17.9)$ & $35.6(31.2)$ & $32.5(29.4)$ & $37.5(25.3)$ & $25.4(22.7)$ & $27.4(22.8)$ & $-9.3(-13.8)$ \\
\hline
\end{tabular}

contribution from a zwitterionic resonance-structure involving an iminium ion at the heterocycle, which restores the aromaticity of the system. Although the trans-geometry is slightly preferred, the cis/trans energy difference is quite small and dihedral scans proved the barrier for isomerization to be lower than the barrier for intramolecular proton transfer (TS-5b), so that trans-5b can be directly converted to cis-5b. Furthermore, up to this point, all steps are reversible so that trans-5b may be recycled to $\mathbf{c i s}-\mathbf{5 b}$. The transition state for an intramolecular proton transfer TS-5b has a free energy barrier of $12.7 \mathrm{kcal} \mathrm{mol}^{-1}$ relative to cis-5b and is likely to be the rate-determining step. While a 1,6-hydride shift has been considered before, the substantial negative charge on the nitrogen in $\mathbf{5 b}$ precludes this mechanistic alternative. The intrinsic reaction coordinate associated with $\mathbf{T S}-\mathbf{5 b}$ leads to azomethine ylide $\mathbf{6 b}$ (Scheme 3 ). A natural population analysis of $\mathbf{6 b}$ shows the negative charge resides mainly on the exocyclic methine carbon, which is rapidly protonated by ethanol (TS-6b). Experimental deuterium labeling studies with EtOD show deuterium incorporation at this position, supporting our proposed mechanism (vide supra). While the enthalpic barrier of TS-6b is negative, the free energy barrier calculated for an ethanol concentration of $17.12 \mathrm{~mol} \mathrm{~L}^{-1}$ has a value of $5.9 \mathrm{kcal} \mathrm{mol}^{-1}$ with respect to $\mathbf{6 b}$. Although we attempted to correct the free energy for the large excess of solvent molecules, it is still substantially overestimated as the entropic penalty for this step can be assumed to be negligible.
The protonation of $\mathbf{6 b}$ is directly followed by deprotonation of the primary amino group by the coordinated ethoxide, which proceeds without a barrier as the resulting zwitterion $7 \mathbf{b}$ is resonance-stabilized. Finally, ring-fused aminal $\mathbf{2 b}$ is formed from $7 \mathbf{b}$ by intramolecular nucleophilic attack on the iminium ion. The free energy barrier for this step is very small $\left(3.3 \mathrm{kcal} \mathrm{mol}^{-1}\right)$, resulting in a very short lifetime of $7 \mathbf{b}$. Product formation is substantially exergonic $\left(-9.4 \mathrm{kcal} \mathrm{mol}^{-1}\right)$ and probably irreversible under the experimental conditions.

Reactions Involving Pyrrolidine, Piperidine, and Morpholine. Inspection of the reactions of pyrrolidine with aldehydes $\mathbf{1 a}$ and $\mathbf{1 b}$ (Scheme 1) reveals dibromo substitution of the aldehyde to give better yields after shorter reaction times. A comparison of the calculated free energies profiles for both reactions (Table 1) shows the reaction of $1 \mathrm{a}$ and pyrrolidine to proceed via lower lying intermediates and transition states. The phenyl ring of aldehyde 1a is electron-deficient and induces a better charge delocalization into the aromatic system in all intermediates and transition states following 3a. This effect is most pronounced in $7 \mathrm{a}$, which is stabilized by $9.6 \mathrm{kcal} \mathrm{mol}^{-1}$ relative to $7 \mathbf{b}$. The formation of hemiaminal $3 \mathbf{a}$ is also more favorable by $1.3 \mathrm{kcal} \mathrm{mol}^{-1}$ than the formation of $3 \mathbf{b}$ owing to the more electrophilic character of the carbonyl group in $\mathbf{1 a}$. The free energy difference between the rate-determining transition states TS-5a and TS-5b is $4.5 \mathrm{kcal} \mathrm{mol}^{-1}$, which is exclusively caused by the change in electronic structure and 
explains the higher yield of the reaction involving aldehyde $\mathbf{2 a}$. Piperidine requires higher reaction temperatures and gives slightly lower yields than pyrrolidine while morpholine gives low yields even at elevated temperatures (eq 2).

The formation of quinoidal intermediates $\mathbf{5 c}$ and $\mathbf{5 d}$ is disfavored in comparison to 5a. Compounds $\mathbf{5 c}$ and $\mathbf{5 d}$ also partly restore the aromaticity of the aryl-ring by adopting a zwitterionic resonance structure, which involves an exocyclic double bond at the iminium ion. The formation of the latter is less favorable in six-membered than in five-membered rings (see the Supporting Information for calculations on model systems). Free energies of TS-5c and TS-5d are higher than that of TS-5a because $\mathbf{5 c}$ and $\mathbf{5 d}$ require more distortion to adopt the transition-state geometries (Figure 3). This does

TS-5a
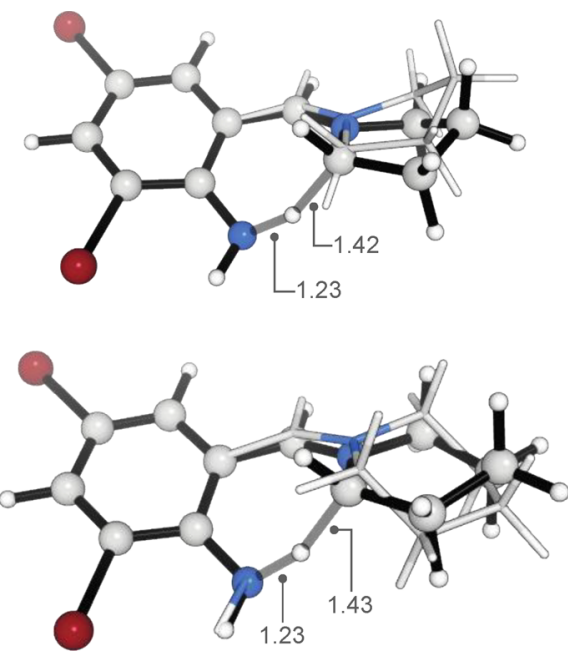

Figure 3. Overlay of the geometries of cis-5a and cis-5c (sticks) with transition states TS-5a and TS-5c (balls and sticks).

explain the better experimental performance of pyrrolidine; however no significant discrimination can be made between piperidine and morpholine based on the energies of the ratelimiting steps TS-5c and TS-5d.

Reactions Involving THIQ and THQ. Our experimental results indicate that products $2 \mathrm{e}$ and $2 \mathrm{~g}$ are obtained under kinetic control, while $\mathbf{2 f}$ and $\mathbf{2 h}$ represent the thermodynamically stable products. Transition-state energies for TS-5e and TS-5g are lower by 6.4 and $6.7 \mathrm{kcal} \mathrm{mol}^{-1}$ than those of TS-5f and TS-5h, respectively, confirming the experimental results. This stabilization is caused by the location of the proton to be abstracted in THIQ which allows an effective delocalization of the resulting charge into the aromatic ring in $6 \mathrm{e}$ and $6 \mathrm{~g}$ (Figure 4 ). However, products $2 \mathrm{e}$ and $\mathbf{2 g}$ are less stable than $\mathbf{2 f}$ and $\mathbf{2 h}$, respectively, which explains their isomerization at prolonged reaction times. Furthermore, $\mathbf{2 g}$ is predicted to be less stable by $4.1 \mathrm{kcal} \mathrm{mol}^{-1}$ than $2 \mathrm{e}$ and thus allows a more facile isomerization.

No product could be obtained at all when THQ was used as an amine instead of THIQ. The high barrier of TS-5i is in good agreement with this finding and is partly caused by a substantial distortion required to transform cis-5i to TS-5i. In addition, the reactions to obtain intermediate cis-5i have a strongly positive reaction free energy $\left(21.1 \mathrm{kcal} \mathrm{mol}^{-1}\right)$ as iminium-like structures involving THQ are energetically disfavored (see the Supporting Information), probably due to the conjugation of the nitrogen lone pair with the aromatic ring.

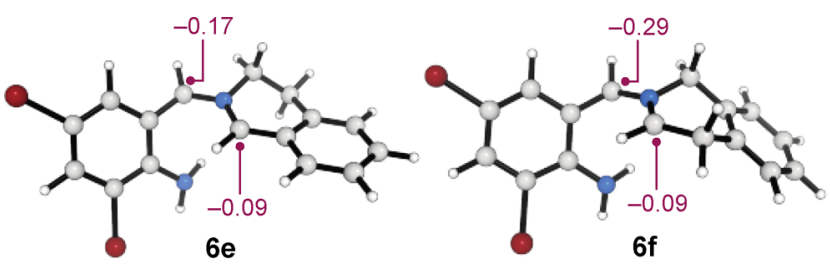

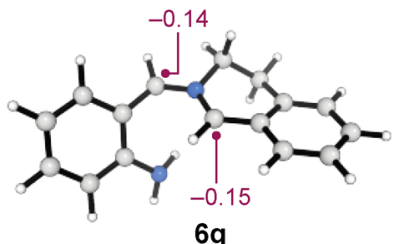

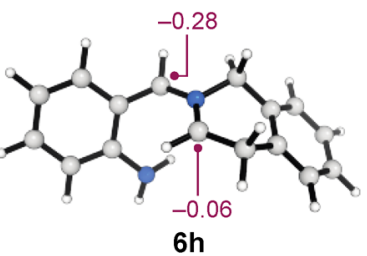

Figure 4. Structures and carbon charges of THIQ azomethine ylides.

Trapping of $6 a$ by a 1,3-Dipolar Cycloaddition. The azo-methine ylide 6 a could be trapped experimentally by a 1,3dipolar cycloaddition with aldehyde 1a. Not surprisingly, the cycloaddition of these highly polar reactants involves a stepwise mechanism with a zwitterionic intermediate 21 (Figure 5).
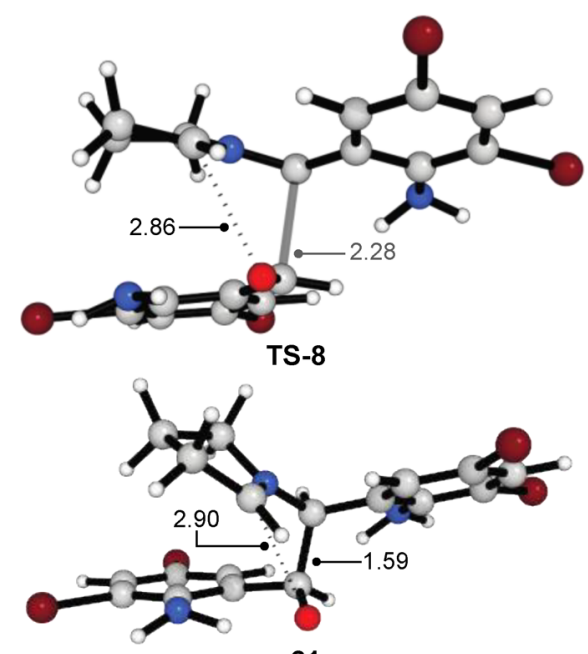

21

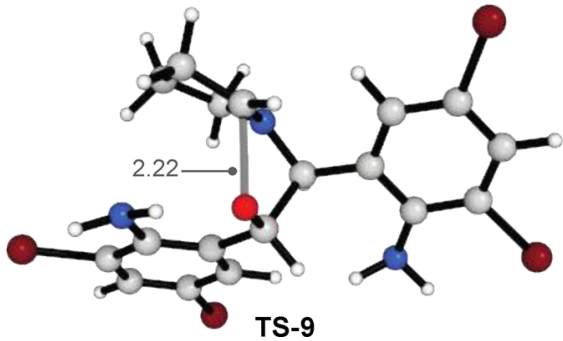

Figure 5. Transition states TS-8 and TS-9 and zwitterionic intermediate $\mathbf{2 1}$ for the $[3+2]$ cycloaddition between $\mathbf{1 a}$ and $\mathbf{6 a}$ (see eq 5). The total reaction is exergonic by $-35.6 \mathrm{kcal} \mathrm{mol}^{-1}$ relative to $1 \mathrm{a}$ and $6 \mathbf{a}$.

Transition-state TS-8 for the first bond formation features a distance of $2.28 \AA$ between the reaction centers while the oxygen and iminium carbon are well separated $(2.86 \AA)$. The calculated barrier of $1.6 \mathrm{kcal} \mathrm{mol}^{-1}$ is significantly lower than any barrier for the amination reaction cascade and indicates that this reaction is essentially diffusion-controlled. However, the rate is limited by the low concentration of azomethine ylide 6a, which is readily protonated by ethanol being present in huge excess. The formation of the zwitterionic intermediate $\mathbf{2 1}$ is 
exergonic by $-8.1 \mathrm{kcal} \mathrm{mol}^{-1}$ and followed by a fast intramolecular ring closure via TS-9. The total cycloaddition reaction is exergonic by $-35.6 \mathrm{kcal} \mathrm{mol}^{-1}$.

\section{CONCLUSIONS}

We have derived a mechanism for the $\alpha$-amination of nitrogen heterocycles by density functional theory calculations involving an unanticipated direct transition of hemiaminals 3 to quinoidal intermediates 5. Our computations are supported by experimental studies including deuterium labeling and trapping of the predicted azaquinone methide and azomethine ylide intermediates. According to our calculations, the rate-limiting step of the entire reaction cascade is an intramolecular proton transfer TS-5; the barrier of this step correlates qualitatively with experimental results. Experimental work toward extending the scope of this reaction in combination with computational predictions is in progress and will be reported in due course.

\section{EXPERIMENTAL SECTION}

General Information. Microwave reactions were carried out in a CEM Discover reactor using sealed $10 \mathrm{~mL}$ reaction vessels, and temperatures were measured with an infrared temperature sensor. Silicon carbide $(\mathrm{SiC})$ passive heating elements were purchased from Anton Paar. Purification of reaction products was carried out by flash column chromatography using Sorbent Technologies Standard grade silica gel (60 ̊, 230-400 mesh). Analytical thin-layer chromatography was performed on EM Reagent $0.25 \mathrm{~mm}$ silica gel $60 \mathrm{~F}_{254}$ plates. Visualization was accomplished with UV light, potassium permanganate, and Dragendorff-Munier stains followed by heating. Proton nuclear magnetic resonance spectra $\left({ }^{1} \mathrm{H}\right.$ NMR) are reported in ppm using the solvent as an internal standard $\left(\mathrm{CDCl}_{3}\right.$ at $7.26 \mathrm{ppm}$, $\left(\mathrm{CD}_{3}\right)_{2} \mathrm{CO}$ at $\left.2.04 \mathrm{ppm}\right)$. Data are reported as app = apparent, $\mathrm{s}=$ singlet, $\mathrm{d}=$ doublet, $\mathrm{t}=$ triplet, $\mathrm{q}=$ quartet, $\mathrm{m}=$ multiplet, comp = complex, br = broad; and coupling constant(s) in Hz. Protondecoupled carbon nuclear magnetic resonance spectra $\left({ }^{13} \mathrm{C} \mathrm{NMR}\right)$ are reported in ppm using the solvent as an internal standard $\left(\mathrm{CDCl}_{3}\right.$ at $77.0 \mathrm{ppm})$.

Aminal 2a. A $10 \mathrm{~mL}$ round-bottom flask was charged with 2-amino-3,5-dibromobenzaldehyde $(0.279 \mathrm{~g}, 1.0 \mathrm{mmol})$, absolute ethanol $(4 \mathrm{~mL})$, and pyrrolidine $(0.246 \mathrm{~mL}, 3.0 \mathrm{mmol})$. The mixture was stirred at reflux under nitrogen for $23 \mathrm{~h}$. After this time, the reaction solvent was removed under reduced pressure and the residue was purified by silica gel chromatography. Compound 2a was recovered as a white solid in $92 \%$ yield $(0.305 \mathrm{~g})\left(R_{f}=0.19\right.$ in hexanes/EtOAc 60:40 v/v): mp 122-124 ${ }^{\circ} \mathrm{C}$; IR (KBr) 3403, 3052, 2971, 2938, 2907, 2839, 1768,1692,1575, 1438, 1349, 1258, 1119, 980, 927, 861, 747, 722, $637 \mathrm{~cm}-1 ;{ }^{1} \mathrm{H}$ NMR $\left(500 \mathrm{MHz}, \mathrm{CDCl}_{3}\right) 7.37$ $(\mathrm{d}, J=1.7 \mathrm{~Hz}, 1 \mathrm{H}), 6.99(\mathrm{~d}, J=0.9 \mathrm{~Hz}, 1 \mathrm{H}), 4.37(\mathrm{ddd}, J=5.2,2.8$, $0.8 \mathrm{~Hz}, 1 \mathrm{H}), 4.23(\mathrm{br} \mathrm{s}, 1 \mathrm{H}), 4.09(\mathrm{~d}, J=16.2 \mathrm{~Hz}, 1 \mathrm{H}), 3.78(\mathrm{~d}, J=$ $16.2 \mathrm{~Hz}, 1 \mathrm{H}), 2.82-2.75$ (comp, $2 \mathrm{H}), 2.20-2.11(\mathrm{~m}, 1 \mathrm{H}), 2.04-1.87$ (comp, 2H), 1.73 (dddd, $J=12.6,9.9,4.2,2.8 \mathrm{~Hz}, 1 \mathrm{H}) ;{ }^{13} \mathrm{C}$ NMR $\left(125 \mathrm{MHz}, \mathrm{CDCl}_{3}\right) \delta 139.6,132.5,129.2,121.7,109.0,108.3,71.3$, 49.9, 49.6, 32.7, 21.7; $\mathrm{m} / \mathrm{z}$ (ESI-MS) $333.0[\mathrm{M}+\mathrm{H}]^{+}$.

Aminal 2b. A $10 \mathrm{~mL}$ round-bottom flask was charged with 2-aminobenzaldehyde $(0.121 \mathrm{~g}, 1.0 \mathrm{mmol})$, absolute ethanol $(4 \mathrm{~mL})$, and pyrrolidine $(0.246 \mathrm{~mL}, 3.0 \mathrm{mmol})$. The mixture was stirred at reflux under nitrogen for $72 \mathrm{~h}$. After this time, the reaction solvent was removed under reduced pressure and the residue was purified by silica gel chromatography. Compound $\mathbf{2 b}$ was recovered as a white solid in $73 \%$ yield $(0.127 \mathrm{~g})\left(R_{f}=0.25\right.$ in $\left.\mathrm{EtOAc} / \mathrm{MeOH} 95: 5 \mathrm{v} / \mathrm{v}\right): \mathrm{mp} 63-$ $64{ }^{\circ} \mathrm{C}$; IR (KBr) 3246, 2966, 2826, 1608, 1585, 1478, 1383, 1255, $749 \mathrm{~cm}^{-1}$; ${ }^{1} \mathrm{H}$ NMR $\left(500 \mathrm{MHz}, \mathrm{CDCl}_{3}\right) 7.02($ app t, $J=7.6 \mathrm{~Hz}, 1 \mathrm{H})$, $6.95($ app d, $J=7.4 \mathrm{~Hz}, 1 \mathrm{H}), 6.70($ app dt, $J=7.4,0.9 \mathrm{~Hz}, 1 \mathrm{H}), 6.54$ (app d, $J=7.9 \mathrm{~Hz}, 1 \mathrm{H}), 4.17-4.13(\mathrm{~m}, 1 \mathrm{H}), 4.04(\mathrm{~d}, J=15.6 \mathrm{~Hz}, 1 \mathrm{H})$, $3.90(\mathrm{~d}, J=15.6 \mathrm{~Hz}, 1 \mathrm{H}), 3.67($ br s, $1 \mathrm{H}), 3.03($ app dt, $J=8.8,5.5 \mathrm{~Hz}$ $1 \mathrm{H}), 2.68(\mathrm{app} \mathrm{dt}, J=8.8,5.5 \mathrm{~Hz}, 1 \mathrm{H}), 2.18-2.09(\mathrm{~m}, 1 \mathrm{H}), 1.97-2.07$ (m, $1 \mathrm{H}), 1.96-1.87(\mathrm{~m}, 1 \mathrm{H}), 1.66$ (app tdd, $J=12.3,10.2,4.4 \mathrm{~Hz}$,
$1 \mathrm{H}) ;{ }^{13} \mathrm{C}$ NMR $\left(125 \mathrm{MHz}, \mathrm{CDCl}_{3}\right) \delta 137.6,133.3,128.6,126.0$, 125.5, 125.2, 124.3, 120.0, 118.9, 115.2, 72.4, 51.9, 50.9, 31.9, 21.3; $\mathrm{m} / z$ (ESI-MS) $175.1[\mathrm{M}+\mathrm{H}]^{+}$

Aminal 2c. To a stirred solution of 2-amino-3,5-dibromobenzaldehyde $(0.279 \mathrm{~g}, 1.0 \mathrm{mmol})$ in 2-propanol $(4 \mathrm{~mL})$ was added piperidine $(0.297 \mathrm{~mL}, 3.0 \mathrm{mmol})$. The mixture was heated to $140{ }^{\circ} \mathrm{C}$ for $48 \mathrm{~h}$ in a sealed tube. After this time, the reaction solvent was removed under reduced pressure and the residue was purified by silica gel chromatography. Compound $2 \mathrm{c}$ was recovered as a white solid in $67 \%$ yield $(0.232 \mathrm{~g})\left(R_{f}=0.28\right.$ in $\mathrm{Hex} /$ EtOAc $\left.70: 30 \mathrm{v} / \mathrm{v}\right): \mathrm{mp} 89-92{ }^{\circ} \mathrm{C}$; IR (KBr) 3405, 2936, 2853, 2771, 1596, 1561, 1486, 1442, 1370, 1351, 1294, 1272, 1190,1119, 856, $713 \mathrm{~cm}^{-1}$; ${ }^{1} \mathrm{H}$ NMR $\left(500 \mathrm{MHz}, \mathrm{CDCl}_{3}\right)$ $7.36(\mathrm{~d}, J=2.1 \mathrm{~Hz}, 1 \mathrm{H}), 6.96(\mathrm{~d}, J=1.4 \mathrm{~Hz}, 1 \mathrm{H}), 4.22(\mathrm{~s}, 1 \mathrm{H}), 3.79$ (br s, $1 \mathrm{H}), 3.72-3.59$ (comp, $2 \mathrm{H}), 2.96-2.88(\mathrm{~m}, 1 \mathrm{H}), 2.25-2.15(\mathrm{~m}$, $1 \mathrm{H}), 1.95-1.87(\mathrm{~m}, 1 \mathrm{H}), 1.76$ (app tt, $J=10.1,4.9 \mathrm{~Hz}, 1 \mathrm{H}), 1.71-1.64$ (comp, $2 \mathrm{H}), 1.63-1.54(\mathrm{~m}, 1 \mathrm{H}), 1.50-1.41(\mathrm{~m}, 1 \mathrm{H}) ;{ }^{13} \mathrm{C} \mathrm{NMR}$ $\left(125 \mathrm{MHz}, \mathrm{CDCl}_{3}\right) \delta 139.1,132.5,128.7,122.3,108.5,108.3,70.2,56.0$, 51.5, 31.9, 25.6. 21.3; $\mathrm{m} / z$ (ESI-MS) $347.0[\mathrm{M}+\mathrm{H}]^{+}$.

Aminal 2d. To a stirred solution of 2-amino-3,5-dibromobenzaldehyde $(0.279 \mathrm{~g}, 1.0 \mathrm{mmol})$ in isopropanol $(4 \mathrm{~mL})$ was added morpholine $(0.260 \mathrm{~mL}, 3.0 \mathrm{mmol})$. The mixture was heated to $140{ }^{\circ} \mathrm{C}$ for $48 \mathrm{~h}$ in a sealed tube. After this time, the reaction solvent was removed under reduced pressure and the residue was purified by silica gel chromatography. Compound $\mathbf{2} \mathbf{d}$ was recovered as a light brown solid in $15 \%$ yield $(0.052 \mathrm{~g})\left(R_{f}=0.15\right.$ in hexanes/EtOAc 80:20 v/v): $\mathrm{mp}$ 156-157 ${ }^{\circ} \mathrm{C}$; IR (KBr) 3344, 2982, 2937, 2901, 2855, 1590, 1492, 1464, 1342, 1315, 1280, 1140, 1121, 1079, 1041, 861, 756, $730 \mathrm{~cm}^{-1}$; ${ }^{1} \mathrm{H} \mathrm{NMR}\left(500 \mathrm{MHz}, \mathrm{CDCl}_{3}\right) 7.42(\mathrm{~s}, 1 \mathrm{H}), 7.00(\mathrm{~s}, 1 \mathrm{H}), 4.25(\mathrm{~s}, 1 \mathrm{H})$, 4.05 (br s, 1H), 3.97 (app d, $J=15.2 \mathrm{~Hz}, 1 \mathrm{H}), 3.91-3.77$ (comp, 3H), $3.72-3.61$ (comp, $2 \mathrm{H}), 2.91-2.84(\mathrm{~m}, 1 \mathrm{H}), 2.42-2.36(\mathrm{~m}, 1 \mathrm{H}) ;{ }^{13} \mathrm{C}$ NMR $\left(125 \mathrm{MHz}, \mathrm{CDCl}_{3}\right) \delta 138.5,132.5,128.8,121.4,109.3,108.9$, 69.2, 67.0, 66.9, 54.7, 48.3; $\mathrm{m} / z$ (ESI-MS) $349.0[\mathrm{M}+\mathrm{H}]^{+}$.

Aminal 2e. To a $10 \mathrm{~mL}$ round-bottom flask with magnetic stir bar were added 2-amino-3,5-dibromobenzaldehyde $(0.279 \mathrm{~g}, 1.0 \mathrm{mmol})$, absolute ethanol $(4 \mathrm{~mL})$, and 1,2,3,4-tetrahydroisoquinoline $(0.381 \mathrm{~mL}$, $3.0 \mathrm{mmol}$ ). The mixture was stirred at reflux under nitrogen for $16 \mathrm{~h}$. After this time the solvent was removed under reduced pressure and the residue was purified by silica gel chromatography. Compound $2 \mathrm{e}$ was recovered as a white solid in $96 \%$ yield $(0.378 \mathrm{~g})\left(R_{f}=0.43\right.$ in hexanes/ EtOAc 80:20 v/v): mp $145-147^{\circ} \mathrm{C}$; IR (KBr) 3408, 3065, 2934, 2899, $2846,1590,1480,1334,1280,1234,1117,1006,991,865,772,735$, $721,685 \mathrm{~cm}^{-1}$; ${ }^{1} \mathrm{H}$ NMR $\left(500 \mathrm{MHz}, \mathrm{CDCl}_{3}\right) 7.43(\mathrm{~d}, J=1.7 \mathrm{~Hz}, 1 \mathrm{H})$, 7.37-7.27 (comp, 3H), 7.22 (app d, J= 7.4 Hz, 1H), 7.07 (s, 1H), 5.28 $(\mathrm{d}, J=2.3 \mathrm{~Hz}, 1 \mathrm{H}), 4.39(\mathrm{~d}, J=16.2 \mathrm{~Hz}, 1 \mathrm{H}), 4.31(\mathrm{~s}, 1 \mathrm{H}), 3.81(\mathrm{~d}, J=$ $16.2 \mathrm{~Hz}, 1 \mathrm{H}), 3.19-3.02$ (comp, $2 \mathrm{H}$ ), 2.97-2.86 (m, 1H), 2.77-2.66 $(\mathrm{m}, 1 \mathrm{H}) ;{ }^{13} \mathrm{C}$ NMR $\left(125 \mathrm{MHz}, \mathrm{CDCl}_{3}\right) \delta 138.7,134.7,134.5,132.4$, 129.2, 128.8, 128.3, 126.5, 126.4, 121.7, 109.0, 108.7, 69.1, 55.3, 44.5, 29.1; $\mathrm{m} / z$ (ESI-MS) $395.0[\mathrm{M}+\mathrm{H}]^{+}$.

Aminal $\mathbf{2 g}$. To a $10 \mathrm{~mL}$ round-bottom flask with a magnetic stir bar were added 2-aminobenzaldehyde $(0.121 \mathrm{~g}, 1.0 \mathrm{mmol})$, absolute ethanol $(4 \mathrm{~mL})$, and 1,2,3,4-tetrahydroisoquinoline $(0.381 \mathrm{~mL}, 3.0 \mathrm{mmol})$. The mixture was stirred at reflux under nitrogen for $48 \mathrm{~h}$. After this time the solvent was removed under reduced pressure, and the residue was purified by silica gel chromatography. Compound $2 \mathrm{~g}$ was recovered as a yellow oil in $96 \%$ yield $(0.227 \mathrm{~g})\left(R_{f}=0.33\right.$ in hexanes $/$ EtOAc 70:30 v/v): IR (KBr) 3387, 3024, 2916, 2837, 2791, 2740, 1725, 1606, $1583,1487,1424,1339,1305,1249,1112,1044,1021,936,749 \mathrm{~cm}^{-1}$; ${ }^{1} \mathrm{H}$ NMR (500 MHz, CDCl3) 7.36 (dd, $\left.J=7.2,1.7 \mathrm{~Hz}, 1 \mathrm{H}\right), 7.30-7.23$ (comp, 2H), $7.20(\mathrm{dd}, J=7.2,1.2 \mathrm{~Hz}, 1 \mathrm{H}), 7.07$ (app t, $J=7.6 \mathrm{~Hz}, 1 \mathrm{H})$, 7.01 (app d, $J=7.5 \mathrm{~Hz}, 1 \mathrm{H}), 6.77($ app dt, $J=7.4,1.1 \mathrm{~Hz}, 1 \mathrm{H}), 6.58$ $(\operatorname{app~d}, J=8.0 \mathrm{~Hz}, 1 \mathrm{H}), 5.16(\mathrm{~d}, J=3.2 \mathrm{~Hz}, 1 \mathrm{H}), 4.35(\mathrm{~d}, J=15.8 \mathrm{~Hz}$, $1 \mathrm{H}), 3.87(\mathrm{~d}, J=15.8 \mathrm{~Hz}, 1 \mathrm{H}), 3.86(\mathrm{br} \mathrm{s}, 1 \mathrm{H}), 3.21$ (ddd $J=11.4,8.3$, $4.8 \mathrm{~Hz}, 1 \mathrm{H}), 3.06$ (ddd, $J=14.0,8.3,5.7 \mathrm{~Hz}, 1 \mathrm{H}), 2.98$ (app td, $J=16.4$, $4.8 \mathrm{~Hz}, 1 \mathrm{H}), 2.72($ app td, $J=10.9,5.3 \mathrm{~Hz}, 1 \mathrm{H}) ;{ }^{13} \mathrm{C}$ NMR $(125 \mathrm{MHz}$, CDCl3) $\delta 142.3,135.8,134.9,129.3,128.1,127.5,127.3,126.5,126.4$, $119.8,118.7,115.6,69.7,56.0,45.5,29.4 ; m / z$ (ESI-MS) $237.1[\mathrm{M}+\mathrm{H}]^{+}$.

Aminal $2 \mathrm{~h}$. A $10 \mathrm{~mL}$ microwave reaction tube was charged with a $10 \times 8 \mathrm{~mm} \mathrm{SiC}$ passive heating element, 2-aminobenzaldehyde $(0.121 \mathrm{~g}, 1.0 \mathrm{mmol}), n-\mathrm{BuOH}(4 \mathrm{~mL})$, and 1,2,3,4-tetrahydroisoquinoline $(0.254 \mathrm{~mL}, 2.0 \mathrm{mmol})$. The reaction tube was sealed with a 
Teflon-lined snap cap and heated in a microwave reactor at $250{ }^{\circ} \mathrm{C}$ (200 W, 80-120 psi) for $2 \mathrm{~h}$. After cooling with compressed air flow, the reaction solvent was removed under reduced pressure and the residue was purified by silica gel chromatography. Compound $2 \mathbf{h}$ was recovered as a yellow solid in $47 \%$ yield $(0.111 \mathrm{~g})$ in addition to $2 \mathrm{~g}$ $(38 \%$ yield, $0.089 \mathrm{~g})$. Characterization data for $2 \mathbf{h}\left(R_{f}=0.14\right.$ in hexanes/EtOAc 80:20 v/v): mp 151-153 ${ }^{\circ} \mathrm{C}$; IR (KBr) 3356, 3032, 2894, 2750, 1612, 1591, 1491, 1452, 1437, 1390, 1368, 1270, 1141, $1125,1093,1020,746,723 \mathrm{~cm}^{-1}$; ${ }^{1} \mathrm{H}$ NMR $\left(500 \mathrm{MHz}, \mathrm{CDCl}_{3}\right) 7.20-$ 7.11 (comp, 3H), 7.07-7.00 (comp, 2H), 6.98 (app d, $J=7.5 \mathrm{~Hz}$, $1 \mathrm{H}), 6.73(\mathrm{app} \mathrm{dt} J=7.5,1.1 \mathrm{~Hz}, 1 \mathrm{H}), 6.50(\mathrm{dd}, J=8.0,0.9 \mathrm{~Hz}, 1 \mathrm{H})$, $4.75-4.68(\mathrm{~m}, 1 \mathrm{H}), 4.38(\mathrm{~d}, J=16.1 \mathrm{~Hz}, 1 \mathrm{H}), 4.03(\mathrm{~d}, J=15.1 \mathrm{~Hz}$, $1 \mathrm{H}), 3.85$ (d, $J=16.1 \mathrm{~Hz}, 1 \mathrm{H}), 3.78-3.67$ (comp, $2 \mathrm{H}), 3.33$ (dd, $J=$ $16.8,4.6 \mathrm{~Hz}, 1 \mathrm{H}), 2.81(\mathrm{dd}, J=16.8,3.1 \mathrm{~Hz}, 1 \mathrm{H}) ;{ }^{13} \mathrm{C}$ NMR $\left(125 \mathrm{MHz}, \mathrm{CDCl}_{3}\right) \delta 142.8,134.0,130.4,128.8,127.5,127.2,126.5$, $126.3,126.0,118.7,118.4,114.8,65.7,54.9,49.6,34.8 ; \mathrm{m} / z$ (ESI-MS) $237.1[\mathrm{M}+\mathrm{H}]^{+}$.

Aminal 2j. A $10 \mathrm{~mL}$ microwave reaction tube was charged with a $10 \times 8 \mathrm{~mm} \mathrm{SiC}$ passive heating element, 2-aminobenzaldehyde $(0.121 \mathrm{~g}$, $1.0 \mathrm{mmol}), n-\mathrm{BuOH}(4 \mathrm{~mL})$, and 2-methylpyrrolidine $(0.306 \mathrm{~mL}$, $3.0 \mathrm{mmol}$ ). The reaction tube was sealed with a Teflon-lined snap cap and heated in a microwave reactor at $250{ }^{\circ} \mathrm{C}(200 \mathrm{~W}, 100-150 \mathrm{psi})$ for $15 \mathrm{~min}$. After cooling with compressed air flow, the reaction solvent was removed under reduced pressure and the residue was purified by silica gel chromatography. Compound $2 \mathbf{j}$ was isolated as a yellow oil in $66 \%$ yield $(0.124 \mathrm{~g})\left(R_{f}=0.27\right.$ in EtOAc): $\mathrm{IR}(\mathrm{KBr}) 3397$, 2970, 1647, 1609, 1493, 1457, 1414, 1354, 1271, 1215, 1131, 1036, $747 \mathrm{~cm}^{-1}$; ${ }^{1} \mathrm{H}$ NMR $\left(500 \mathrm{MHz}, \mathrm{CDCl}_{3}\right) 7.01($ app t, $J=7.8 \mathrm{~Hz}, 1 \mathrm{H})$, $6.95($ app d, $J=7.4 \mathrm{~Hz}, 1 \mathrm{H}), 6.64($ app t, $J=7.4 \mathrm{~Hz}, 1 \mathrm{H}), 6.43$ (app d, $J=7.8 \mathrm{~Hz}, 1 \mathrm{H}), 4.23(\mathrm{~d}, J=17.0 \mathrm{~Hz}, 1 \mathrm{H}), 3.75(\mathrm{~d}, J=17.0 \mathrm{~Hz}, 1 \mathrm{H})$, 3.59 (br s, 1H), 3.01 (app td, $J=8.4,4.4 \mathrm{~Hz}, 1 \mathrm{H}), 2.75$ (app q, $J=$ $8.4 \mathrm{~Hz}, 1 \mathrm{H}), 1.98-1.75$ (comp, 4H), $1.41(\mathrm{~s}, 3 \mathrm{H}) ;{ }^{13} \mathrm{C}$ NMR $\left(125 \mathrm{MHz}, \mathrm{CDCl}_{3}\right) \delta 142.0,127.4,127.1,117.0,116.6,114.0,73.1$, $50.8,45.3,39.8,25.5,19.8 ; \mathrm{m} / z$ (ESI-MS) $189.0[\mathrm{M}+\mathrm{H}]^{+}$.

In addition, compound $2 \mathbf{k}$ was isolated as a yellow oil as a mixture of diastereomers in $26 \%$ yield $(0.049 \mathrm{~g}), \mathrm{dr}=54: 46$ as determined by integration of one set of ${ }^{1} \mathrm{H}$ NMR signals $\left(\delta_{\text {major }} 1.26 \mathrm{ppm}, \delta_{\text {minor }} 1.16\right.$ ppm) $\left(R_{f}=0.45\right.$ in EtOAc): IR (KBr) 3386, 2961, 2870, 1608, 1494, $1375,1302,1262,1154,1041,747 \mathrm{~cm}^{-1}$; ${ }^{1} \mathrm{H}$ NMR of major diastereomer $\left(500 \mathrm{MHz}, \mathrm{CDCl}_{3}\right) 7.08-6.98$ (comp, 2H), 6.77 (app $\mathrm{dt}, J=7.4,1.1 \mathrm{~Hz}, 1 \mathrm{H}), 6.70-6.64($ comp, $1 \mathrm{H}), 4.07(\mathrm{~d}, J=13.9 \mathrm{~Hz}$, $1 \mathrm{H}), 3.99(\mathrm{br} \mathrm{s}, 1 \mathrm{H}), 3.65-3.57(\mathrm{~m}, 1 \mathrm{H}), 3.46(\mathrm{~d}, J=13.9 \mathrm{~Hz}, 1 \mathrm{H})$, 2.49-2.39 (m, 1H), 2.25-1.97 (comp, 2H), 1.74-1.48 (comp, 2H), $1.26(\mathrm{~d}, J=6.1 \mathrm{~Hz}, 3 \mathrm{H}) ;{ }^{13} \mathrm{C} \mathrm{NMR}\left(125 \mathrm{MHz}, \mathrm{CDCl}_{3}\right) \delta 143.1,143.0$, 127.4, 127.1, 127.0, 121.7, 119.2, 117.6, 117.2, 116.8, 113.6, 74.2, 70.8, 58.6, 53.3, 52.6, 45.7, 31.0, 30.7, 29.7, 28.8, 19.5, 18.6; $\mathrm{m} / z$ (ESI-MS) $189.0[\mathrm{M}+\mathrm{H}]^{+}$.

Synthesis of Aminoaldehyde 11. To a $25 \mathrm{~mL}$ round-bottom flask with fitted with a magnetic stir bar were added 2-aminobenzyl alcohol (0.246 g, $2.00 \mathrm{mmol})$, methanol $(6.25 \mathrm{~mL})$, (E)-ethyl 7-oxohept-2-enoate ${ }^{27 \mathrm{a}}(0.374 \mathrm{~g}, 2.20 \mathrm{mmol})$, and acetic acid $(0.321$ $\mathrm{mL}, 5.6 \mathrm{mmol}$ ). The resulting solution was cooled to $0{ }^{\circ} \mathrm{C}$ in an ice bath, and sodium cyanoborohydride $(0.189 \mathrm{~g}, 3.00 \mathrm{mmol})$ was added. The solution was allowed to warm to room temperature and was stirred for $1 \mathrm{~h}$, after which time the reaction was quenched with $5 \mathrm{~mL}$ of $5 \%$ aq $\mathrm{KHSO}_{4}$ solution. The product was extracted with EtOAc $(2 \times 10 \mathrm{~mL})$, and the extract was washed with satd $\mathrm{NaHCO}_{3}(1 \times 10 \mathrm{~mL})$ followed by brine $(1 \times 10 \mathrm{~mL})$. The organic layer was dried over sodium sulfate, filtered, and dried in vacuo. The crude product was purified by silica gel chromatography, and ethyl 7-((2-(hydroxymethyl)phenyl)amino)hept2-enoate $\left(\mathbf{1 1}^{\prime}\right)$ was obtained as a colorless oil in $91 \%$ yield $(0.503 \mathrm{~g})$ as a mixture of stereoisomers; ratio $E / Z=3.55: 1\left(R_{f}=0.23\right.$ in hexanes/ EtOAc 80:20 v/v). Characterization data of the $E$ isomer: IR $(\mathrm{KBr})$ 3391, 2931, 1716, 1652, 1607, 1520, 1456, 1312, 1192, 1038, 927, 822, $748 \mathrm{~cm}^{-1}$; ${ }^{1} \mathrm{H}$ NMR $\left(500 \mathrm{MHz}, \mathrm{CDCl}_{3}\right) 7.21$ (app td, $J=7.8,1.6 \mathrm{~Hz}$, $1 \mathrm{H}), 7.04(\mathrm{dd}, J=7.8,1.3 \mathrm{~Hz}, 1 \mathrm{H}), 6.96(\mathrm{app} \mathrm{dt}, J=15.6,6.9 \mathrm{~Hz}, 1 \mathrm{H})$, 6.67-6.62 (comp, 2H), $5.83(\mathrm{dt}, J=15.6,1.5 \mathrm{~Hz}, 1 \mathrm{H}), 4.63(\mathrm{~s}, 2 \mathrm{H})$, $4.17(\mathrm{q}, J=7.1 \mathrm{~Hz}, 2 \mathrm{H}), 3.15(\mathrm{t}, J=6.9 \mathrm{~Hz}, 2 \mathrm{H}), 2.25$ (app qd, $J=7.2$, $1.4 \mathrm{~Hz}, 2 \mathrm{H}), 1.73-1.65$ (comp, $2 \mathrm{H}), 1.64-1.57$ (comp, $2 \mathrm{H}), 1.28(\mathrm{t}, J=$ $7.1 \mathrm{~Hz}, 3 \mathrm{H}) ;{ }^{13} \mathrm{C}$ NMR $\left(125 \mathrm{MHz}, \mathrm{CDCl}_{3}\right) \delta 166.7,148.7,147.6,129.5$,
129.0, 124.2, 121.6, 116.2, 110.4, 64.7, 60.2, 43.1, 31.8, 28.8, 25.5, 14.2; $\mathrm{m} / z$ (ESI-MS) $278.1[\mathrm{M}+\mathrm{H}]^{+}$.

A $10 \mathrm{~mL}$ round-bottom flask with a stir bar was charged with $11^{\prime}$ $(0.277 \mathrm{~g}, 1 \mathrm{mmol}$, ratio of stereoisomers $(E / Z)=3.55: 1)$, dichloromethane $(3.57 \mathrm{~mL})$, and manganese dioxide $(0.522 \mathrm{~g}, 6.00$ $\mathrm{mmol}$ ), and the resulting solution was stirred at room temperature for $20 \mathrm{~h}$. The reaction mixture was filtered through a pad of Celite and rinsed with dichloromethane $(3 \times 20 \mathrm{~mL})$. The solvent was removed in vacuo and the residue was purified by silica gel chromatography, yielding both $E$ and $Z$ isomers. Pure $E$-isomer 11 was obtained as a bright yellow oil in $62 \%$ yield $(0.198 \mathrm{~g})\left(R_{f}=0.31\right.$ in hexanes/EtOAc 90:10 v/v): IR (KBr) 3331, 2984, 2745, 1647, 1521, 1457, 1265, 1040, 981, 870, 749 $\mathrm{cm}^{-1}$; ${ }^{1} \mathrm{H}$ NMR $\left(500 \mathrm{MHz}, \mathrm{CDCl}_{3}\right.$ ) $9.81(\mathrm{~s}, 1 \mathrm{H}), 8.31$ (br s, $\left.1 \mathrm{H}\right), 7.46$ $(\mathrm{dd}, J=7.9,1.4 \mathrm{~Hz}, 1 \mathrm{H}), 7.42-7.35(\mathrm{~m}, 1 \mathrm{H}), 6.95$ (app dt, $J=15.6,6.9$ $\mathrm{Hz}, 1 \mathrm{H}), 6.75-6.63$ (comp, $2 \mathrm{H}), 5.87-5.81(\mathrm{~m}, 1 \mathrm{H}), 4.18(\mathrm{q}, J=7.1$ $\mathrm{Hz}, 2 \mathrm{H}), 3.33-3.19(\mathrm{~m}, 2 \mathrm{H}), 2.36-2.21(\mathrm{~m}, 2 \mathrm{H}), 1.81-1.68(\mathrm{~m}, 2 \mathrm{H})$, $1.67-1.56(\mathrm{~m}, 2 \mathrm{H}), 1.28(\mathrm{t}, J=7.1 \mathrm{~Hz}, 3 \mathrm{H}) ;{ }^{13} \mathrm{C} \mathrm{NMR}(125 \mathrm{MHz}$, $\left.\mathrm{CDCl}_{3}\right) \delta 193.9,166.5,150.7,148.3,136.7,135.8,121.8,118.3,114.7$, $110.7,60.2,42.1,31.8,28.5,25.5,14.2 ; \mathrm{m} / z$ (ESI-MS) $276.3[\mathrm{M}+\mathrm{H}]^{+}$.

Compound 12. To a $5 \mathrm{~mL}$ round-bottom flask were added aldehyde $11(0.25 \mathrm{mmol}, 0.069 \mathrm{~g})$, absolute ethanol $(1 \mathrm{~mL})$ and pyrrolidine $(0.75 \mathrm{mmol}, 0.062 \mathrm{~mL})$. The resulting mixture was stirred at reflux for $48 \mathrm{~h}$. The reaction mixture was cooled to room temperature and solvent was removed in vacuo. The residue was purified via silica gel chromatography (hexanes/EtOAc 80:20 v/v EtOAc/MeOH/NEt 3 74:25:1 v/v/v). Racemic compound 12 was obtained as a tan oil in $7 \%$ yield $(0.0060 \mathrm{~g})\left(R_{f}=0.44\right.$ in hexanes/ EtOAc 80:20 v/v). Relative stereochemistry was determined using 2D NMR and J-coupling analysis: IR (KBr) 3329, 2933, 1717, 1654, 1577, $1522,1458,1338,1160,1041,751 \mathrm{~cm}^{-1} ;{ }^{1} \mathrm{H}$ NMR $(500 \mathrm{MHz}$, $\left.\left(\mathrm{CD}_{3}\right)_{2} \mathrm{CO}\right) 7.08$ (app td, $\left.J=7.3,1.7 \mathrm{~Hz}, 1 \mathrm{H}\right), 6.94$ (dd, $J=7.3$, $1.7 \mathrm{~Hz}, 1 \mathrm{H}), 6.78(\operatorname{app~d}, J=8.2 \mathrm{~Hz}, 1 \mathrm{H}), 6.53($ app td, $J=7.3,3.3 \mathrm{~Hz}$, $1 \mathrm{H}), 4.28-4.20(\mathrm{~m}, 1 \mathrm{H}), 4.15-4.01$ (comp, $3 \mathrm{H}), 3.47$ (app td, $J=$ 10.7, $2.2 \mathrm{~Hz}, 1 \mathrm{H}$ ), 2.87 (app t, $J=12.8,1 \mathrm{H}), 2.62-2.54$ (dd, $J=10.7$, $4.7 \mathrm{~Hz}, 1 \mathrm{H}) 2.54-2.47(\mathrm{~m}, 2 \mathrm{H}), 2.40-2.29(\mathrm{~m}, 2 \mathrm{H}), 1.99-1.93$ $(\mathrm{m}, 1 \mathrm{H}), 1.87-1.81(\mathrm{~m}, 1 \mathrm{H}), 1.71-1.65(\mathrm{~m}, 1 \mathrm{H}), 1.62-1.46$ (comp, $6 \mathrm{H}), 1.25(\mathrm{t}, J=7.1 \mathrm{~Hz}, 3 \mathrm{H}), 1.09-0.99(\mathrm{~m}, 1 \mathrm{H}) ;{ }^{13} \mathrm{C} \mathrm{NMR}$ $\left(125 \mathrm{MHz}, \mathrm{CDCl}_{3}\right) \delta 172.2,145.5,130.1,128.7,115.3,111.5,109.7$, $60.2,59.5,54.7,51.8,50.9,48.0,33.5,25.4,24.9,23.4,14.2 ; \mathrm{m} / z$ (ESI-MS) $327.5[\mathrm{M}-\mathrm{H}]^{+}$.

In addition, compound $\mathbf{1 3}$ was isolated as a yellow oil in 7\% yield $(0.0044 \mathrm{~g})\left(R_{f}=0.47\right.$ in hexanes/EtOAc 90:10 v/v): IR $(\mathrm{KBr}) 3419$, 2360, 2090, 1649, 1559, 1540, 1507, $1457 \mathrm{~cm}^{-1}$; ${ }^{1} \mathrm{H}$ NMR (500 MHz, $\left.\mathrm{CDCl}_{3}\right) 7.32(\mathrm{~s}, 1 \mathrm{H}), 7.18-7.14(\mathrm{~m}, 1 \mathrm{H}), 7.01(\mathrm{dd}, J=7.4,1.2 \mathrm{~Hz}$, $1 \mathrm{H}), 6.65-6.57$ (comp, 2H), $4.45(\mathrm{dd}, J=10.8,1.9 \mathrm{~Hz}, 1 \mathrm{H}), 4.30-$ $4.19(\mathrm{~m}, 2 \mathrm{H}), 3.94(\operatorname{app~d}, J=13.6 \mathrm{~Hz}, 1 \mathrm{H}), 3.07-2.97(\mathrm{~m}, 1 \mathrm{H})$, $1.85-1.79(\mathrm{~m}, 1 \mathrm{H}), 1.78-1.65$ (comp, $3 \mathrm{H}), 1.54-1.44$ (comp, $2 \mathrm{H})$, $1.33(\mathrm{t}, J=7.1 \mathrm{~Hz}, 3 \mathrm{H}) ;{ }^{13} \mathrm{C} \mathrm{NMR}\left(125 \mathrm{MHz}, \mathrm{CDCl}_{3}\right) \delta 165.6,145.5$, 134.9, 132.1, 130.1, 124.5, 120.6, 116.7, 111.2, 60.4, 58.2, 46.7, 28.9, 25.0, 22.1, 14.3; $\mathrm{m} / \mathrm{z}$ (ESI-MS) $256.3[\mathrm{M}-\mathrm{H}]^{+}$.

In addition, compound 14 was isolated as a tan oil in $42 \%$ yield $(0.0370 \mathrm{~g})\left(R_{f}=0.20\right.$ in hexanes $/$ EtOAc $\left.70: 30 \mathrm{v} / \mathrm{v}\right)$ : IR $(\mathrm{KBr}) 3447$, 2936, 2870, 2115, 1732, 1652, 1578, 1521, 1459, 1200, 1160, 1039, $751 \mathrm{~cm}^{-1}$; ${ }^{1} \mathrm{H} \mathrm{NMR}\left(500 \mathrm{MHz}, \mathrm{CDCl}_{3}\right) 9.80(\mathrm{~s}, 1 \mathrm{H}), 8.29(\mathrm{br} \mathrm{s}, 1 \mathrm{H})$, 7.46-7.41 (m, 1H), 7.39-7.33 (m, 1H), 6.69-6.62 (comp, $2 \mathrm{H}), 4.12$ (q, $J=7.1 \mathrm{~Hz}, 2 \mathrm{H}), 3.29-3.15$ (comp, $2 \mathrm{H}), 3.02-2.93(\mathrm{~m}, 1 \mathrm{H})$, 2.64-2.48 (comp, 5H), 2.32 (ddd, $J=14.7,7.3,2.3 \mathrm{~Hz}, 1 \mathrm{H}$ ), 1.801.63 (comp, 6H), 1.63-1.44 (comp, 4H), $1.24(\mathrm{t}, J=7.1 \mathrm{~Hz}, 3 \mathrm{H}) ;{ }^{13} \mathrm{C}$ NMR $\left(125 \mathrm{MHz}, \mathrm{CDCl}_{3}\right) \delta 193.8,172.9,150.8,136.7,135.7,118.2$, $114.5,110.7,60.3,58.6,49.5,42.4,36.4,32.6,29.2,23.5,23.2$, 14.2; $\mathrm{m} / z$ (ESI-MS) $347.2[\mathrm{M}+\mathrm{H}]^{+}$.

In addition, compound $\mathbf{1 5}$ was isolated as a tan oil in $22 \%$ yield $(0.0228 \mathrm{~g})\left(R_{f}=0.09\right.$ in $\left.i-\mathrm{PrNH}_{2} / \mathrm{MeOH} / \mathrm{EtOAc} 1: 25: 74 \mathrm{v} / \mathrm{v} / \mathrm{v}\right):$ IR (KBr) 3421, 2931, 1733, 1654,1497, 1458, 1374, $1033 \mathrm{~cm}^{-1} ;{ }^{1} \mathrm{H}$ NMR $\left(500 \mathrm{MHz}, \mathrm{CDCl}_{3}\right) 7.08$ (app t, $\left.J=7.8 \mathrm{~Hz}, 1 \mathrm{H}\right), 6.91$ (app d, $J=7.3 \mathrm{~Hz}, 1 \mathrm{H}), 6.66-6.59(\mathrm{comp}, 2 \mathrm{H}), 4.13(\mathrm{q}, J=7.1 \mathrm{~Hz}, 2 \mathrm{H}), 3.89$ $($ app t $J=5.7 \mathrm{~Hz}, 1 \mathrm{H}), 3.85(\mathrm{~d}, J=14.6 \mathrm{~Hz}, 1 \mathrm{H}), 3.79(\mathrm{~d}, J=14.6 \mathrm{~Hz}$, $1 \mathrm{H}), 3.34-3.26(\mathrm{~m}, 1 \mathrm{H}), 3.14-3.01$ (comp, $2 \mathrm{H}), 2.99-2.92(\mathrm{~m}, 1 \mathrm{H})$, 2.61-2.51 (comp, 5H), 2.34 (dd, $J=14.8,7.3 \mathrm{~Hz}, 1 \mathrm{H}$ ), 2.14-2.06 (m, $1 \mathrm{H}), 1.99-1.80$ (comp, 4H), 1.78-1.72 (comp, 4H), 1.66-1.48 
(comp, 4H), 1.43-1.33 (comp, 2H), $1.25(\mathrm{t}, J=7.1 \mathrm{~Hz}, 3 \mathrm{H}) ;{ }^{13} \mathrm{C} \mathrm{NMR}$ $\left(125 \mathrm{MHz}, \mathrm{CDCl}_{3}\right) \delta 173.0,144.7,144.6,127.4,126.9,121.0,120.9$, 116.6, 112.0, 60.3, 58.8, 52.3, 51.6, 49.6, 47.6, 47.5, 36.5, 36.4, 32.7, 30.6, 27.4, 27.3, 23.5, 23.4, 20.6, 14.2; $\mathrm{m} / z$ (ESI-MS) $400.2[\mathrm{M}+\mathrm{H}]^{+}$.

Aminoaldehyde 18. To a $5 \mathrm{~mL}$ round-bottom flask were added aldehyde $11(0.25 \mathrm{mmol}, 0.069 \mathrm{~g})$, absolute ethanol $(1 \mathrm{~mL})$, and piperidine $(0.75 \mathrm{mmol}, 0.074 \mathrm{~mL})$. The resulting mixture was stirred at reflux for $96 \mathrm{~h}$. The reaction mixture was cooled to room temperature, and solvent was removed in vacuo. The residue was purified via silica gel chromatography (hexanes/EtOAc 80:20 v/v$\mathrm{EtOAc} / \mathrm{MeOH} / \mathrm{NEt}_{3}$ 74:25:1 v/v/v). Compound 18 was obtained as an orange oil in $47 \%$ yield $(0.0421 \mathrm{~g})\left(R_{f}=0.32\right.$ in hexanes/EtOAc $50: 50 \mathrm{v} / \mathrm{v}): \mathrm{IR}(\mathrm{KBr}) 3328,2933,2854,2740,1731,1651,1610,1580$, $1520,1462,1335,1234,1159,1113,1038,877,750,663 \mathrm{~cm}^{-1} ;{ }^{1} \mathrm{H}$ NMR $\left(500 \mathrm{MHz}, \mathrm{CDCl}_{3}\right) 9.79$ (s, 1H), 8.30 (br s, 1H), 7.44 (app d, $J=7.8 \mathrm{~Hz}, 1 \mathrm{H}), 7.36$ (app t, $J=7.8 \mathrm{~Hz}, 1 \mathrm{H}), 6.75-6.70($ comp, $2 \mathrm{H})$, $4.11(\mathrm{q}, J=7.1 \mathrm{~Hz}, 2 \mathrm{H}), 3.21(\mathrm{dd}, J=12.7,6.6 \mathrm{~Hz}, 2 \mathrm{H}), 3.02-2.91$ $(\mathrm{m}, 1 \mathrm{H}), 2.52(\mathrm{dd}, J=14.2,6.8 \mathrm{~Hz}, 1 \mathrm{H}), 2.49-2.43$ (comp, $2 \mathrm{H})$, $2.42-2.35$ (comp, $2 \mathrm{H}$ ), 2.15 (dd, $J=14.2,6.8 \mathrm{~Hz}, 1 \mathrm{H}), 1.74-1.63$ (comp, 2H), 1.61-1.28 (comp, 10H), $1.24(\mathrm{t}, J=7.1 \mathrm{~Hz}, 3 \mathrm{H}) ;{ }^{13} \mathrm{C}$ NMR $\left(125 \mathrm{MHz}, \mathrm{CDCl}_{3}\right) \delta 193.7,173.3,150.8,136.6,135.7,118.2$, 114.5, 110.7, 61.6, 60.1, 49.4, 42.4, 35.1, 30.7, 28.9, 26.5, 24.9, 24.2, 14.2; $\mathrm{m} / z$ (ESI-MS) $361.2[\mathrm{M}+\mathrm{H}]^{+}$.

$\mathrm{N}, \mathrm{O}$-Acetal 20. A $10 \mathrm{~mL}$ microwave reaction tube was charged with a $10 \times 8 \mathrm{~mm} \mathrm{SiC}$ passive heating element, 2-amino-3,5-dibromobenzaldehyde $(0.279 \mathrm{~g}, 1.0 \mathrm{mmol})$, PhMe $(1 \mathrm{~mL})$, and pyrrolidine $(0.041 \mathrm{~mL}, 0.5 \mathrm{mmol})$. The reaction tube was sealed with a Teflon-lined snap cap and heated in a microwave reactor at $150{ }^{\circ} \mathrm{C}(200 \mathrm{~W}, 30-60$ psi) for $30 \mathrm{~min}$. After cooling with compressed air flow, the reaction mixture was loaded directly onto a column and purified by silica gel chromatography. Racemic compound $\mathbf{2 0}$ was obtained as a tan solid in $27 \%$ yield $(0.0809 \mathrm{~g})$ in addition to $2 \mathrm{a}$ ( $58 \%$ yield, $0.0957 \mathrm{~g}$ ). Characterization data for $20\left(R_{f}=0.53\right.$ in hexanes $/$ EtOAc 60:40 v/v). Relative stereochemistry was determined using $2 \mathrm{D}$ NMR and J-coupling analysis: $\mathrm{mp} 153-156^{\circ} \mathrm{C}$; IR (KBr) $3438,3393,3344,2961,1607,1577$, 1570, 1507, 1484, 1458, 1379, 1340, 1286, 1264, 1195, 1170, 1050, 865, $739 \mathrm{~cm}^{-1}$; ${ }^{1} \mathrm{H}$ NMR $\left(500 \mathrm{MHz}, \mathrm{CDCl}_{3}\right) 7.59(\mathrm{~d}, J=2.2 \mathrm{~Hz}, 1 \mathrm{H}), 7.39$ $(\mathrm{d}, J=2.1 \mathrm{~Hz}, 1 \mathrm{H}), 6.71(\mathrm{~d}, J=2.2 \mathrm{~Hz}, 1 \mathrm{H}), 5.88(\mathrm{~d}, J=2.1 \mathrm{~Hz}, 1 \mathrm{H})$, $5.01($ br s, $2 \mathrm{H}), 4.76($ app d, $J=4.6 \mathrm{~Hz}, 1 \mathrm{H}), 4.39(\mathrm{~d}, J=9.8 \mathrm{~Hz}, 1 \mathrm{H})$, 4.34 (br s, $1 \mathrm{H}), 4.15(\mathrm{~d}, J=9.8 \mathrm{~Hz}, 1 \mathrm{H}), 3.11($ app td, $J=8.8,3.2 \mathrm{~Hz}$, $1 \mathrm{H}$ ), 2.69 (app q, $J=8.8 \mathrm{~Hz}, 1 \mathrm{H}$ ), 2.28-2.17 (m, 1H), 2.08-1.94 (comp, $2 \mathrm{H}), 1.93-1.84(\mathrm{~m}, 1 \mathrm{H}) ;{ }^{13} \mathrm{C} \mathrm{NMR}\left(125 \mathrm{MHz}, \mathrm{CDCl}_{3}\right) \delta 142.6,137.9$, 134.2, 133.2, 132.9, 132.2, 124.5, 117.8, 111.5, 108.5, 108.2, 107.2, 77.3, 64.2, 58.3, 50.0, 33.1, 20.8; $\mathrm{m} / z$ (ESI-MS) $611.8[\mathrm{M}+\mathrm{H}]^{+}$.

Aminal 2a (Partially Deuterated According to eq 6). To a $10 \mathrm{~mL}$ round-bottom flask fitted with a magnetic stir bar were added 2-amino-3,5-dibromobenzaldehyde $(0.279 \mathrm{~g}, 1.0 \mathrm{mmol})$, EtOD $(4 \mathrm{~mL})$, and pyrrolidine $(0.246 \mathrm{~mL}, 3.0 \mathrm{mmol})$. The resulting mixture was stirred at reflux for $24 \mathrm{~h}$. After this time, the solvent was removed under reduced pressure and the product was dissolved in EtOAc $(10 \mathrm{~mL})$. This solution was washed with distilled water $(3 \times 10 \mathrm{~mL})$, dried over sodium sulfate, filtered, and concentrated in vacuo. The resultant residue was purified by silica gel chromatography. Compound 2a was recovered as a white solid in $77 \%$ yield $(0.257 \mathrm{~g})\left(R_{f}=0.33\right.$ in hexanes/EtOAc 60:40 v/v): IR (KBr) 3404, 3053, 2971, 2937, 2903, 2839, 1591, 1482, 1333, 1277, 1239, 1222, 1132, 880, $724 \mathrm{~cm}^{-1}$; $1 \mathrm{H}$ NMR $\left(500 \mathrm{MHz}, \mathrm{CDCl}_{3}\right) 7.39(\mathrm{~d}, J=2.1 \mathrm{~Hz}, 1 \mathrm{H}), 7.02-6.99(\mathrm{~m}, 1 \mathrm{H})$, 4.47-4.36 (m, 1H), 4.24 (br s, $1 \mathrm{H}), 4.15-4.06$ (comp, $1 \mathrm{H}, 50 \% \mathrm{D})$, 3.84-3.75 (comp, 1H, 54\% D), 2.91-2.73 (comp, 2H), 2.24-2.11 (m, $1 \mathrm{H}), 2.08-1.88$ (comp, $2 \mathrm{H}), 1.81-1.68(\mathrm{~m}, 1 \mathrm{H}) ; \mathrm{m} / z$ (ESI-MS) $334.1[\mathrm{M}+\mathrm{H}]^{+}$.

Aminal 2e (Partially Deuterated According to eq 7). To a $10 \mathrm{~mL}$ round-bottom flask fitted with a magnetic stir bar were added 2-amino-3,5-dibromobenzaldehyde (0.279 g, $1.0 \mathrm{mmol})$, EtOD $(4 \mathrm{~mL})$, and 1,2,3,4-tetrahydroisoquinoline $(0.381 \mathrm{~mL}, 3.0 \mathrm{mmol})$. The resulting mixture was stirred at reflux for $16 \mathrm{~h}$. After this time, the solvent was removed under reduced pressure and the product was dissolved in $\mathrm{CH}_{2} \mathrm{Cl}_{2}(10 \mathrm{~mL})$. This solution was washed with distilled water $(3 \times 10 \mathrm{~mL})$, dried over sodium sulfate, filtered, and concentrated in vacuo. The resultant residue was purified by silica gel chromatography. Compound $2 \mathbf{e}$ was recovered as a white solid in $95 \%$ yield $(0.375 \mathrm{~g})\left(R_{f}=0.43\right.$ in hexanes/EtOAc 80:20 v/v): IR (KBr) 3408, 3066, 2955, 2911, 2847, 1509, 1480, 1365, 1316, 1281, 1163, 1117, 991, 865, 735, $721 \mathrm{~cm}^{-1}$; ${ }^{1} \mathrm{H}$ NMR (500 MHz, $\mathrm{CDCl}_{3}$ ) 7.44 (d, $J=2.0 \mathrm{~Hz}, 1 \mathrm{H}), 7.37-7.25$ (comp, 3H), 7.22 (app d, $J=7.4 \mathrm{~Hz}$, $1 \mathrm{H}), 7.07$ (d, $J=1.5 \mathrm{~Hz}, 1 \mathrm{H}), 5.32-5.23$ (comp, 1H, 33\% D), 4.434.34 (comp, $1 \mathrm{H}, 33 \% \mathrm{D}$ ), 4.34-4.28 (comp, 1H), 3.84-3.73 (comp, $1 \mathrm{H}$, $37 \%$ D), 3.17-3.02 (comp, 2H), 2.97-2.86 (m, 1H), 2.74-2.64 (m, $1 \mathrm{H}) ; m / z$ (ESI-MS) $395.3[\mathrm{M}+\mathrm{H}]^{+}$.

Aminal 2e (Partially Deuterated According to eq 8). $\mathrm{N}, \mathrm{N}$ Dideutero-2-amino-3,5-dibromobenzaldehyde was produced by dissolving 2-amino-3,5-dibromobenzaldehyde $(0.279 \mathrm{~g}, 1.0 \mathrm{mmol})$ in EtOD (1 mL), heating to reflux, allowing to cool to room temperature, removing solvent in vacuo, and repeating this process two more times. 1-Hydro-2-deutero-3,4-dihydroisoquinoline was produced from 1,2,3,4-tetrahydroisoquinoline $(0.381 \mathrm{~mL}, 3.0 \mathrm{mmol})$ using the same process. To a $10 \mathrm{~mL}$ round-bottom flask fitted with a magnetic stir bar were added $\mathrm{N}, \mathrm{N}$-dideutero-2-amino-3,5-dibromobenzaldehyde $(0.281 \mathrm{~g}$, $1.0 \mathrm{mmol})$, EtOD (4 mL), and 1-hydro-2-deutero-3,4-dihydroisoquinoline $(0.403 \mathrm{~g}, 3.0 \mathrm{mmol})$. The resulting mixture was stirred at reflux for $24 \mathrm{~h}$. After this time, the solvent was removed under reduced pressure and the product was dissolved in $\mathrm{CH}_{2} \mathrm{Cl}_{2}(10 \mathrm{~mL})$. This solution was washed with distilled water $(3 \times 10 \mathrm{~mL})$, dried over sodium sulfate, filtered, and concentrated in vacuo. The resultant residue was purified by silica gel chromatography. Compound $2 \mathbf{e}$ was isolated as a white solid in $87 \%$ yield $(0.344 \mathrm{~g})\left(R_{f}=0.43\right.$ in hexanes/EtOAc 80:20 v/v): IR $(\mathrm{KBr})$ 3413, 3065, 3023, 2932, 2913, 2868, 2154, 1590, 1475, 1356, 1281, $1013,1001,863,730,721,703,685,550 \mathrm{~cm}^{-1} ;{ }^{1} \mathrm{H}$ NMR $(500 \mathrm{MHz}$, $\left.\mathrm{CDCl}_{3}\right) 7.44$ (d, $\left.J=2.0 \mathrm{~Hz}, 1 \mathrm{H}\right), 7.37-7.25$ (comp, 3H), 7.22 (app d, $J=7.4 \mathrm{~Hz}, 1 \mathrm{H}), 7.07(\mathrm{~d}, J=1.5 \mathrm{~Hz}, 1 \mathrm{H}), 5.32-5.23($ comp, $1 \mathrm{H}$, $30 \%$ D), 4.43-4.34 (comp, 1H, 40\% D), 4.34-4.28 (comp, 1H), 3.843.73 (comp, $1 \mathrm{H}, 44 \% \mathrm{D}), 3.17-3.02$ (comp, $2 \mathrm{H}), 2.97-2.86(\mathrm{~m}, 1 \mathrm{H})$, 2.74-2.64 (m, 1H); $m / z$ (ESI-MS) $397.3[\mathrm{M}+\mathrm{H}]^{+}$.

In addition, partially deuterated THIQ was isolated as a colorless liquid in $98 \%$ yield $(0.392 \mathrm{~g})\left(R_{f}=0.13\right.$ in $i-\mathrm{PrNH}_{2} / \mathrm{MeOH} / \mathrm{EtOAc}$ $2: 10: 78 \mathrm{v} / \mathrm{v} / \mathrm{v}$ ): IR ( $\mathrm{KBr}) 3316,2922,2360,1496,1454,1261,1120$, $745 \mathrm{~cm}^{-1}$; ${ }^{1} \mathrm{H}$ NMR (500 MHz, $\mathrm{CDCl}_{3}$ ) 7.17-7.04 (comp, 3H), 7.00 (app t, $J=4.2 \mathrm{~Hz}, 1 \mathrm{H}), 4.04-3.95$ (comp, $1 \mathrm{H}, 12.5 \% \mathrm{D}), 3.14(\mathrm{t}, J=$ $5.8 \mathrm{~Hz}, 2 \mathrm{H}), 2.80(\mathrm{t}, J=5.8 \mathrm{~Hz}, 2 \mathrm{H}), 1.70(\mathrm{~s}, 1 \mathrm{H}) ; \mathrm{m} / z(\mathrm{ESI}-\mathrm{MS})$ $134.3[\mathrm{M}+\mathrm{H}]^{+}$.

Aminal 2a (Partially Deuterated According to eq 9). To a $10 \mathrm{~mL}$ round-bottom flask fitted with a magnetic stir bar were added 2-amino-3,5-dibromobenzaldehyde $(0.279 \mathrm{~g}, 1.0 \mathrm{mmol})$, absolute ethanol $(2 \mathrm{~mL})$, EtOD $(2 \mathrm{~mL})$, and pyrrolidine $(0.246 \mathrm{~mL}, 3.0 \mathrm{mmol})$. The resulting mixture was stirred at reflux for $24 \mathrm{~h}$. After this time, the solvent was removed under reduced pressure, and the product was dissolved in EtOAc $(10 \mathrm{~mL})$. This solution was washed with distilled water $(3 \times 10 \mathrm{~mL})$, dried over sodium sulfate, filtered, and concentrated in vacuo. The resultant residue was purified by silica gel chromatography. $2 \mathrm{a}$ was recovered as a white solid in $85 \%$ yield $(0.283 \mathrm{~g})$ $\left(R_{f}=0.33\right.$ in hexanes/EtOAc 60:40 v/v): IR (KBr) 3403, 3054, 2937, 2906, 2839, 1592, 1485, 1347, 1291, 1222, 1148, 1119, 979, 881, 861, 747, $725 \mathrm{~cm}^{-1}$; ${ }^{1} \mathrm{H}$ NMR $\left(500 \mathrm{MHz}, \mathrm{CDCl}_{3}\right) 7.37(\mathrm{dd}, J=2.1,0.6 \mathrm{~Hz}, 1 \mathrm{H})$, 6.98 (d, $J=0.9 \mathrm{~Hz}, 1 \mathrm{H}), 4.37$ (ddd, $J=5.0,2.6,0.8 \mathrm{~Hz}, 1 \mathrm{H}), 4.23$ (br s, $1 \mathrm{H}), 4.12-4.03$ (comp, $1 \mathrm{H}, 14 \% \mathrm{D}), 3.81-3.74$ (comp, $1 \mathrm{H}, 18 \% \mathrm{D})$, 2.89-2.71 (comp, 2H), 2.27-2.09 (m, 1H), 2.09-1.84 (comp, 2H), 1.73 (dddd, $J=12.6,9.8,4.2,2.6 \mathrm{~Hz}, 1 \mathrm{H}) ; \mathrm{m} / z$ (ESI-MS) $333.0[\mathrm{M}+\mathrm{H}]^{+}$.

Aminal 2e (Partially Deuterated According to eq 10). To a $10 \mathrm{~mL}$ round-bottom flask fitted with a magnetic stir bar were added 2-amino-3,5-dibromobenzaldehyde (0.279 g, $1.0 \mathrm{mmol})$, absolute ethanol $(2 \mathrm{~mL})$, EtOD $(2 \mathrm{~mL})$, and 1,2,3,4-tetrahydroisoquinoline $(0.381 \mathrm{~mL}, 3.0 \mathrm{mmol})$. The resulting mixture was stirred at reflux for $16 \mathrm{~h}$. After this time, the solvent was removed under reduced pressure and the product was dissolved in $\mathrm{CH}_{2} \mathrm{Cl}_{2}(10 \mathrm{~mL})$. This solution was washed with distilled water $(3 \times 10 \mathrm{~mL})$, dried over sodium sulfate, filtered, and concentrated in vacuo. The resultant residue was purified by silica gel chromatography. Compound $2 \mathbf{e}$ was recovered as a white solid in $95 \%$ yield $(0.377 \mathrm{~g})\left(R_{f}=0.43\right.$ in hexanes/EtOAc 80:20 v/v): IR (KBr) 3411, 2932, 2345, 1735, 1718, 1654, 1648, 1590, 1480, 1458, $1281,1162,1120,736 \mathrm{~cm}^{-1} ;{ }^{1} \mathrm{H}$ NMR $\left(500 \mathrm{MHz}, \mathrm{CDCl}_{3}\right) 7.43$ (d, J= 
$1.7 \mathrm{~Hz}, 1 \mathrm{H}$ ), 7.37-7.27 (comp, 3H), 7.22 (app d, $J=7.4 \mathrm{~Hz}, 1 \mathrm{H}$ ), 7.07 (s, 1H), 5.29-5.26 (comp, 1H, 13\% D), 4.42-4.35 (comp, 1H, 6\% D), 4.34-4.28 (comp, 1H), 3.84-3.76 (comp, 1H, 10\% D), 3.133.02 (comp, $2 \mathrm{H}), 2.97-2.86(\mathrm{~m}, 1 \mathrm{H}), 2.74-2.64(\mathrm{~m}, 1 \mathrm{H}) ; \mathrm{m} / z$ (ESIMS) $395.0[\mathrm{M}+\mathrm{H}]^{+}$.

Aminal 2a (Partially Deuterated According to eq 11). To a $10 \mathrm{~mL}$ round-bottom flask fitted with a magnetic stir bar were added 2-amino-3,5-dibromobenzaldehyde $(0.279 \mathrm{~g}, 1.0 \mathrm{mmol})$, absolute ethanol $(4 \mathrm{~mL})$, and 2,2-dideuteropyrrolidine ${ }^{27 \mathrm{~b}}(0.219 \mathrm{~g}, 3.0 \mathrm{mmol})$. The resulting mixture was stirred at reflux for 3.5 days. After this time, the solvent was removed under reduced pressure and the product was dissolved in EtOAc $(10 \mathrm{~mL})$. This solution was washed with distilled water $(3 \times 10 \mathrm{~mL})$, dried over sodium sulfate, filtered, and concentrated in vacuo. The resultant residue was purified by silica gel chromatography. Compound $2 \mathrm{a}$ was recovered as a white solid in $77 \%$ yield $(0.258 \mathrm{~g})\left(R_{f}=0.33\right.$ in hexanes $/$ EtOAc $\left.60: 40 \mathrm{v} / \mathrm{v}\right):$ IR (KBr) 3404, 3055, 2937, 2902, 2839, 2083, 1592, 1483, 1438, 1348, 1266, 1159, 1123, 963, 866, $741 \mathrm{~cm}^{-1}$; ${ }^{1} \mathrm{H}$ NMR $\left(500 \mathrm{MHz}, \mathrm{CDCl}_{3}\right)$ $7.39(\mathrm{dd}, J=2.1,0.6 \mathrm{~Hz}, 1 \mathrm{H}), 7.00(\mathrm{~d}, J=0.9 \mathrm{~Hz}, 1 \mathrm{H}), 4.48-4.36$ (comp, 1H, 22\% D), 4.24 (br s, $1 \mathrm{H}), 4.12(\mathrm{~d}, J=16.3 \mathrm{~Hz}, 1 \mathrm{H}), 3.79$ (d, $J=16.3 \mathrm{~Hz}, 1 \mathrm{H}), 2.83-2.77$ (comp, $2 \mathrm{H}, 78 \% \mathrm{D}), 2.21-2.12$ (m, 1H), 2.06-1.87 (comp, 2H), 1.74 (dddd, $J=12.6,9.8,4.2,2.7 \mathrm{~Hz}$, $1 \mathrm{H}) ; \mathrm{m} / z$ (ESI-MS) $335.1[\mathrm{M}+\mathrm{H}]^{+}$.

Aminal 2e (Partially Deuterated According to eq 12). To a $10 \mathrm{~mL}$ round-bottom flask fitted with a magnetic stir bar were added 2-amino-3,5-dibromobenzaldehyde (0.279 g, $1.0 \mathrm{mmol})$, absolute ethanol $(4 \mathrm{~mL})$, and 1-deutero-1,2,3,4-tetrahydroisoquinoline $\mathrm{e}^{27 \mathrm{c}}$ $(0.403 \mathrm{~g}, 3.0 \mathrm{mmol})$. The resulting mixture was stirred at reflux for $16 \mathrm{~h}$. After this time, the solvent was removed under reduced pressure and the product was dissolved in $\mathrm{CH}_{2} \mathrm{Cl}_{2}(10 \mathrm{~mL})$. This solution was washed with distilled water $(3 \times 10 \mathrm{~mL})$, dried over sodium sulfate, filtered, and concentrated in vacuo. The resultant residue was purified by silica gel chromatography. Compound $2 \mathbf{e}$ was recovered as a white solid in $96 \%$ yield $(0.381 \mathrm{~g})\left(R_{f}=0.43\right.$ in hexanes $/$ EtOAc 80:20 v/v): IR (KBr) 3408, 3066, 2954, 2911, 2846, 2154, 1590, 1474, 1281, 1138, 1117, 1012, 997, 862, 769, 729, $683 \mathrm{~cm}^{-1}$; ${ }^{1} \mathrm{H}$ NMR (500 MHz, $\left.\mathrm{CDCl}_{3}\right) 7.42$ (d, $\left.J=2.1 \mathrm{~Hz}, 1 \mathrm{H}\right), 7.35-7.25$ (comp, 3H), 7.21 (app d, $J=7.4 \mathrm{~Hz}, 1 \mathrm{H}), 7.06(\mathrm{~d}, J=0.8 \mathrm{~Hz}, 1 \mathrm{H}), 5.29-5.25(\mathrm{comp}, 1 \mathrm{H}, 65 \% \mathrm{D})$, 4.42-4.34 (comp, 1H), 4.34-4.26 (comp, $1 \mathrm{H}), 3.79$ (d, $J=16.3 \mathrm{~Hz}$, $1 \mathrm{H}), 3.18-3.02$ (comp, $2 \mathrm{H}), 2.98-2.85(\mathrm{~m}, 1 \mathrm{H}), 2.76-2.64(\mathrm{~m}, 1 \mathrm{H})$; $\mathrm{m} / z$ (ESI-MS) $395.0[\mathrm{M}+\mathrm{H}]^{+}$.

Aminal 2e (Partially Deuterated According to eq 13). To a $10 \mathrm{~mL}$ round-bottom flask fitted with a magnetic stir bar were added 2-amino-3,5-dibromobenzaldehyde (0.279 g, $1.0 \mathrm{mmol})$, absolute ethanol $(4 \mathrm{~mL}), 1,2,3,4$-tetrahydroisoquinoline $(0.190 \mathrm{~mL}, 1.5 \mathrm{mmol})$, and 1,1-dideutero-3,4-dihydro- $2 \mathrm{H}$-isoquinoline ${ }^{27 \mathrm{~d}}(0.203 \mathrm{~g}, 1.5 \mathrm{mmol})$. The resulting mixture was stirred at reflux for $16 \mathrm{~h}$. After this time, the solvent was removed under reduced pressure and the product was dissolved in $\mathrm{CH}_{2} \mathrm{Cl}_{2}(10 \mathrm{~mL})$. This solution was washed with distilled water $(3 \times 10 \mathrm{~mL})$, dried over sodium sulfate, filtered, and concentrated in vacuo. The resultant residue was purified by silica gel chromatography. Compound 2e was recovered as a white solid in $96 \%$ yield $(0.378 \mathrm{~g})$ $\left(R_{f}=0.43\right.$ in hexanes/EtOAc 80:20 v/v): IR ( $\left.\mathrm{KBr}\right) 3412,3064,2932$, 2905, 2867, 1590, 1478, 1338, 1280, 1162, 1121, 1030, 1004, 861, 770, 736, $722,686 \mathrm{~cm}^{-1}$; ${ }^{1} \mathrm{H}$ NMR $\left(500 \mathrm{MHz}, \mathrm{CDCl}_{3}\right) 7.44(\mathrm{~d}, J=2.1 \mathrm{~Hz}$, $1 \mathrm{H}), 7.37-7.26$ (comp, 3H), 7.22 (app d, $J=7.5 \mathrm{~Hz}, 1 \mathrm{H}), 7.07$ (d, $J=1.0 \mathrm{~Hz}, 1 \mathrm{H}), 5.30-5.24$ (comp, $1 \mathrm{H}, 34 \% \mathrm{D}), 4.42-4.35$ (comp, $1 \mathrm{H}$ ), 4.34-4.29 (comp, 1H), 3.80 (d, $J=16.2 \mathrm{~Hz}, 1 \mathrm{H}), 3.17-3.03$ (comp, $2 \mathrm{H}), 2.98-2.85(\mathrm{~m}, 1 \mathrm{H}), 2.76-2.65(\mathrm{~m}, 1 \mathrm{H}) ; \mathrm{m} / z$ (ESI-MS) 395.9 $[\mathrm{M}+\mathrm{H}]^{+}$.

\section{ASSOCIATED CONTENT}

\section{S Supporting Information}

NMR spectra for all reported compounds. Cartesian coordinates, energies, and thermodynamic corrections for all reported structures. This information is available free of charge via the Internet at http://pubs.acs.org.

\section{AUTHOR INFORMATION}

\section{Corresponding Author}

*E-mail: houk@chem.ucla.edu, seidel@rutchem.rutgers.edu.

Notes

The authors declare no competing financial interest.

\section{ACKNOWLEDGMENTS}

This work used the Extreme Science and Engineering Discovery Environment (XSEDE), which is supported by National Science Foundation Grant No. OCI-1053575 as well as the UCLA Academic Technology Services (ATS) Hoffman Beowulf cluster. We are grateful to the Alexander von Humboldt foundation (Feodor Lynen fellowship to A.D.) and the National Science Foundation for support of this research through Grant No. CHE-1059084 to K.N.H. Financial support from the NIHNIGMS through Grant No. R01GM101389-01 to D.S. is gratefully acknowledged. Partial support (microwave purchase) was provided by the National Science Foundation through Grant No. CHE-0911192 to D.S. A.Y.P. gratefully acknowledges financial support from the Russian Federation President Grant (order N2057). D.S. is a fellow of the Alfred P. Sloan Foundation and the recipient of an Amgen Young Investigator Award.

\section{REFERENCES}

(1) Hiersemann, M. In Comprehensive Organic Functional Group Transformations II; Katritzky, A. R. T., Richard, J. K., Ed.; Elsevier: Oxford, 2005; Vol. 4, p 411.

(2) For selected examples of aminal-containing natural products, see: (a) Hino, T.; Nakagawa, M. In Alkaloids; Academic Press: New York, 1988; Vol. 34, p 1. (b) Hubbs, J. L.; Heathcock, C. H. Org. Lett. 1999, 1, 1315. (c) Snider, B. B.; Zeng, H. B. Org. Lett. 2002, 4, 1087. (d) Movassaghi, M.; Schmidt, M. A. Angew. Chem., Int. Ed. 2007, 46, 3725. (e) Crich, D.; Banerjee, A. Acc. Chem. Res. 2007, 40, 151. (f) Kuroda, T.; Kigoshi, H. Org. Lett. 2008, 10, 489. (g) Wang, S. H.; Romo, D. Angew. Chem., Int. Ed. 2008, 47, 1284. (h) Dounay, A. B.; Humphreys, P. G.; Overman, L. E.; Wrobleski, A. D. J. Am. Chem. Soc. 2008, 130, 5368. (i) Pham, V.; Jossang, A.; Grellier, P.; Sevenet, T.; Nguyen, V.; Bodo, B. J. Org. Chem. 2008, 73, 7565. (j) Zhang, M.; Huang, X. P.; Shen, L. Q.; Qin, Y. J. Am. Chem. Soc. 2009, 131, 6013.

(3) (a) Zhang, C.; De, C. K.; Mal, R.; Seidel, D. J. Am. Chem. Soc. 2008, 130, 416. (b) Zhang, C.; De, C. K.; Seidel, D. Org. Synth. 2012, 89, 274.

(4) For related studies, see: (a) Cohen, N.; Blount, J. F.; Lopresti, R. J.; Trullinger, D. P. J. Org. Chem. 1979, 44, 4005. (b) Zheng, L.; Yang, F.; Dang, Q.; Bai, X. Org. Lett. 2008, 10, 889. (c) Polshettiwar, V.; Varma, R. S. Tetrahedron Lett. 2008, 49, 7165. (d) Bi, H.-P.; Zhao, L.; Liang, Y.-M.; Li, C.-J. Angew. Chem., Int. Ed. 2009, 48, 792. (e) Bi, H.P.; Chen, W.-W.; Liang, Y.-M.; Li, C.-J. Org. Lett. 2009, 11, 3246. (f) Bi, H.-P.; Teng, Q.; Guan, M.; Chen, W.-W.; Liang, Y.-M.; Yao, X.; Li, C.-J. J. Org. Chem. 2010, 75, 783.

(5) The term redox-neutral refers to the fact that this transformation does not require a terminal oxidant. For reviews on redox-economy, see: (a) Burns, N. Z.; Baran, P. S.; Hoffmann, R. W. Angew. Chem., Int. Ed. 2009, 48, 2854. (b) Newhouse, T.; Baran, P. S.; Hoffmann, R. W. Chem. Soc. Rv. 2009, 38, 3010.

(6) For selected articles on redox-neutral amine $\alpha$-functionalization, see: (a) Ten Broeke, J.; Douglas, A. W.; Grabowski, E. J. J. J. Org. Chem. 1976, 41, 3159. (b) Pastine, S. J.; McQuaid, K. M.; Sames, D. J. Am. Chem. Soc. 2005, 127, 12180. (c) Tobisu, M.; Chatani, N. Angew. Chem., Int. Ed. 2006, 45, 1683. (d) Indumathi, S.; Kumar, R. R.; Perumal, S. Tetrahedron 2007, 63, 1411. (e) Ryabukhin, S. V.; Plaskon, A. S.; Volochnyuk, D. M.; Shivanyuk, A. N.; Tolmachev, A. A. Synthesis 2007, 2872. (f) Belskaia, N. P.; Deryabina, T. G.; Koksharov, A. V.; Kodess, M. I.; Dehaen, W.; Lebedev, A. T.; Bakulev, V. A. Tetrahedron Lett. 2007, 48, 9128. (g) Oda, M.; Fukuchi, Y.; Ito, S.; Thanh, N. C.; Kuroda, S. Tetrahedron Lett. 2007, 48, 9159. (h) Polonka-Balint, A.; 
Saraceno, C.; Ludányi, K.; Bényei, A.; Matyus, P. Synlett 2008, 2846. (i) Barluenga, J.; Fananas-Mastral, M.; Aznar, F.; Valdes, C. Angew. Chem., Int. Ed. 2008, 47, 6594. (j) Mori, K.; Ohshima, Y.; Ehara, K.; Akiyama, T. Chem. Lett. 2009, 38, 524. (k) Ruble, J. C.; Hurd, A. R.; Johnson, T. A.; Sherry, D. A.; Barbachyn, M. R.; Toogood, P. L.; Bundy, G. L.; Graber, D. R.; Kamilar, G. M. J. Am. Chem. Soc. 2009, 131, 3991. (1) Cui, L.; Peng, Y.; Zhang, L. J. Am. Chem. Soc. 2009, 131, 8394. (m) Pahadi, N. K.; Paley, M.; Jana, R.; Waetzig, S. R.; Tunge, J. A. J. Am. Chem. Soc. 2009, 131, 16626. (n) Dunkel, P.; Turos, G.; Benyei, A.; Ludanyi, K.; Matyus, P. Tetrahedron 2010, 66, 2331. (o) Cui, L.; Ye, L.; Zhang, L. Chem. Commun. 2010, 46, 3351. (p) Zhou, G.; Zhang, J. Chem. Commun. 2010, 46, 6593. (q) Kang, Y. K.; Kim, S. M.; Kim, D. Y. J. Am. Chem. Soc. 2010, 132, 11847. (r) Mao, H.; Xu, R.; Wan, J.; Jiang, Z.; Sun, C.; Pan, Y. Chem.-Eur. J. 2010, 16, 13352. (s) Ruiz, M. D. R.; Vasella, A. Helv. Chim. Acta 2011, 94, 785. (t) Barluenga, J.; Fananas-Mastral, M.; Fernandez, A.; Aznar, F. Eur. J. Org. Chem. 2011, 1961. (u) Zhou, G. H.; Liu, F.; Zhang, J. L. Chem.-Eur. J. 2011, 17, 3101. (v) Ghavtadze, N.; Narayan, R.; Wibbeling, B.; Wuerthwein, E. U. J. Org. Chem. 2011, 76, 5185. (w) Mori, K.; Ehara, K.; Kurihara, K.; Akiyama, T. J. Am. Chem. Soc. 2011, 133, 6166. (x) Cao, W. D.; Liu, X. H.; Wang, W. T.; Lin, L. L.; Feng, X. M. Org. Lett. 2011, 13, 600. (y) Xue, X. S.; Yu, A.; Cai, Y.; Cheng, J. P. Org. Lett. 2011, 13, 6054. (z) He, Y. P.; Du, Y. L.; Luo, S. W.; Gong, L. Z. Tetrahedron Lett. 2011, 52, 7064. (aa) Mahoney, S. J.; Fillion, E. Chem.-Eur. J. 2012, 18, 68. (ab) Jurberg, I. D.; Peng, B.; Woestefeld, E.; Wasserloos, M.; Maulide, N. Angew. Chem., Int. Ed. 2012, 51, 1950. (ac) Sugiishi, T.; Nakamura, H. J. Am. Chem. Soc. 2012, 134, 2504. (ad) Han, Y. Y.; Han, W. Y.; Hou, X.; Zhang, X. M.; Yuan, W. C. Org. Lett. 2012, 14, 4054. (ae) Chen, L. J.; Zhang, L.; Lv, J.; Cheng, J. P.; Luo, S. Z. Chem.-Eur. J. 2012, 18, 8891. (af) Zhang, L.; Chen, L.; Lv, J.; Cheng, J.-P.; Luo, S. Chem. Asian J. 2012, 7, 2569.

(7) For other examples from our lab, see: (a) Zhang, C.; Murarka, S.; Seidel, D. J. Org. Chem. 2009, 74, 419. (b) Murarka, S.; Zhang, C.; Konieczynska, M. D.; Seidel, D. Org. Lett. 2009, 11, 129. (c) Murarka, S.; Deb, I.; Zhang, C.; Seidel, D. J. Am. Chem. Soc. 2009, 131, 13226. (d) Zhang, C.; Seidel, D. J. Am. Chem. Soc. 2010, 132, 1798. (e) Deb, I.; Seidel, D. Tetrahedron Lett. 2010, 51, 2945. (f) Haibach, M. C.; Deb, I.; De, C. K.; Seidel, D. J. Am. Chem. Soc. 2011, 133, 2100. (g) Zhang, C.; Das, D.; Seidel, D. Chem. Sci. 2011, 2, 233. (h) Deb, I.; Das, D.; Seidel, D. Org. Lett. 2011, 13, 812. (i) Deb, I.; Coiro, D. J.; Seidel, D. Chem. Commun. 2011, 47, 6473. (j) Das, D.; Richers, M. T.; Ma, L.; Seidel, D. Org. Lett. 2011, 13, 6584. (k) Ma, L.; Chen, W.; Seidel, D. J. Am. Chem. Soc. 2012, 134, 15305.

(8) For selected reviews on amine $\alpha$-functionalization, see: (a) Murahashi, S.-I. Angew. Chem., Int. Ed. Engl. 1995, 34, 2443. (b) Doye, S. Angew. Chem., Int. Ed. 2001, 40, 3351. (c) Matyus, P.; Elias, O.; Tapolcsanyi, P.; Polonka-Balint, A.; Halasz-Dajka, B. Synthesis 2006, 2625. (d) Campos, K. R. Chem. Soc. Rev. 2007, 36, 1069. (e) Murahashi, S. I.; Zhang, D. Chem. Soc. Rev. 2008, 37, 1490. (f) Li, C.-J. Acc. Chem. Res. 2009, 42, 335. (g) Yoo, W. J.; Li, C. J. Top. Curr. Chem. 2010, 292, 281. (h) Jazzar, R.; Hitce, J.; Renaudat, A.; Sofack-Kreutzer, J.; Baudoin, O. Chem.-Eur. J. 2010, 16, 2654. (i) Yeung, C. S.; Dong, V. M. Chem. Rev. 2011, 111, 1215. (j) Sun, C. L.; Li, B. J.; Shi, Z. J. Chem. Rev. 2011, 111, 1293. (k) Liu, C.; Zhang, H.; Shi, W.; Lei, A. W. Chem. Rev. 2011, 111, 1780. (1) Wendlandt, A. E.; Suess, A. M.; Stahl, S. S. Angew. Chem., Int. Ed. 2011, 50, 11062. (m) Jones, K. M.; Klussmann, M. Synlett 2012, 23, 159. (n) Zhang, C.; Tang, C. H.; Jiao, N. Chem. Soc. Rev. 2012, 41, 3464. (o) Mitchell, E. A.; Peschiulli, A.; Lefevre, N.; Meerpoel, L.; Maes, B. U. W. Chem.Eur. J. 2012, 18, 10092.

(9) For selected reports on $o$-azaquinone methides, see: (a) Steinhagen, H.; Corey, E. J. Angew. Chem., Int. Ed. 1999, 38, 1928. (b) Wojciechowski, K. Eur. J. Org. Chem. 2001, 3587. (c) Modrzejewska, H.; Wojciechowski, K. Synlett 2008, 2465. (d) Wang, C.; Pahadi, N.; Tunge, J. A. Tetrahedron 2009, 65, 5102. (e) Robertson, F. J.; Kenimer, B. D.; Wu, J. Tetrahedron 2011, 67, 4327.

(10) For selected reviews on azomethine ylide chemistry, see: (a) Padwa, A. 1,3-Dipolar Cycloaddition Chemistry; Wiley: New York, 1984; Vol. 1. (b) Padwa, A., Ed. 1,3-Dipolar Cycloaddition Chemistry;
Wiley: New York, 1984; Vol. 2. (c) Padwa, A.; Pearson, W. H. Synthetic Applications of 1,3-Dipolar Cycloaddition Chemistry Toward Heterocycles and Natural Products; Wiley: Chichester, 2002; Vol. 59. (d) Najera, C.; Sansano, J. M. Curr. Org. Chem. 2003, 7, 1105. (e) Coldham, I.; Hufton, R. Chem. Rev. 2005, 105, 2765. (f) Pandey, G.; Banerjee, P.; Gadre, S. R. Chem. Rev. 2006, 106, 4484. (g) Pinho e Melo, T. M. V. D. Eur. J. Org. Chem. 2006, 2873. (h) Bonin, M.; Chauveau, A.; Micouin, L. Synlett 2006, 2349. (i) Nair, V.; Suja, T. D. Tetrahedron 2007, 63, 12247. (j) Najera, C.; Sansano, J. M. Top. Heterocycl. Chem. 2008, 12, 117. (k) Stanley, L. M.; Sibi, M. P. Chem. Rev. 2008, 108, 2887. (1) Nyerges, M.; Toth, J.; Groundwater, P. W. Synlett 2008, 1269. (m) Pineiro, M.; Pinho e Melo, T. M. V. D. Eur. J. Org. Chem. 2009, 5287. (n) Burrell, A. J. M.; Coldham, I. Curr. Org. Synth. 2010, 7, 312. (o) Anac, O.; Gungor, F. S. Tetrahedron 2010, 66, 5931. (p) Adrio, J.; Carretero, J. C. Chem. Commun. 2011, 47, 6784.

(11) The formation of azomethine ylides via the deprotonation of iminium ions is an established concept. For example, see: (a) Huisgen, R.; Grashey, R.; Steingruber, E. Tetrahedron Lett. 1963, 1441. (b) Toth, G.; Frank, J.; Bende, Z.; Weber, L.; Simon, K. J. Chem. Soc., Perkin Trans. 1 1983, 1961. (c) Ardill, H.; Grigg, R.; Sridharan, V.; Surendrakumar, S.; Thianpatanagul, S.; Kanajun, S. J. Chem. Soc., Chem. Commun. 1986, 602. (d) Kanemasa, S.; Takenaka, S.; Watanabe, H.; Tsuge, O. J. Org. Chem. 1989, 54, 420. (e) Ardill, H.; Fontaine, X. L. R.; Grigg, R.; Henderson, D.; Montgomery, J.; Sridharan, V.; Surendrakumar, S. Tetrahedron 1990, 46, 6449. (f) Grigg, R; Sridharan, V.; Thornton-Pett, M.; Wang, J.; Xu, J.; Zhang, J. Tetrahedron 2002, 58, 2627.

(12) For selected reports in which 1,6-proton transfers have been invoked, see: (a) Meth-Cohn, O.; Naqui, M. A. Chem. Commun. 1967, 1157. (b) Klop, W.; Brandsma, L. J. Chem. Soc., Chem. Commun. 1983, 988. (c) Fang, J. M.; Yang, C. C.; Wang, Y. W. J. Org. Chem. 1989, 54, 481. (d) Bourhis, M.; Vercauteren, J. Tetrahedron Lett. 1994, 35, 1981. (e) Noguchi, M.; Mizukoshi, T.; Uchida, T.; Kuroki, Y. Tetrahedron 1996, 52, 13097. (f) Reinhard, R.; Glaser, M.; Neumann, R.; Maas, G. J. Org. Chem. 1997, 62, 7744. (g) Noguchi, M.; Yamada, H.; Takamura, S.; Okada, K.; Kakehi, A.; Yamamoto, H. Tetrahedron 2000, 56, 1299. (h) Noguchi, M.; Shirai, M.; Nakashima, K.; Arai, I.; Nishida, A.; Yamamoto, H.; Kakehi, A. Tetrahedron 2003, 59, 4581. (i) Yin, G. W.; Zhu, Y. X.; Lu, P.; Wang, Y. G. J. Org. Chem. 2011, 76, 8922.

(13) For selected reports in which 1,6-hydride shifts have been invoked, see: (a) Reinhoudt, D. N.; Visser, G. W.; Verboom, W.; Benders, P. H.; Pennings, M. L. M. J. Am. Chem. Soc. 1983, 105, 4775. (b) Verboom, W.; Reinhoudt, D. N.; Visser, R.; Harkema, S. J. Org. Chem. 1984, 49, 269. (c) Jiang, S.; Janousek, Z.; Viehe, H. G. Tetrahedron Lett. 1994, 35, 1185. (d) De Boeck, B.; Jiang, S.; Janousek, Z.; Viehe, H. G. Tetrahedron 1994, 50, 7075. (e) De Boeck, B.; Janousek, Z.; Viehe, H. G. Tetrahedron 1995, 51, 13239. (f) Pigeon, P.; Mamouni, A.; Sikoraiova, J.; Marchalin, S.; Decroix, B. Tetrahedron 2001, 57, 4939. (g) Ryabukhin, S. V.; Plaskon, A. S.; Volochnyuk, D. M.; Shivanyuk, A. N.; Tolmachev, A. A. J. Org. Chem. 2007, 72, 7417. (h) Che, X.; Zheng, L.; Dang, Q.; Bai, X. Synlett 2008, 2373. (i) Vasu, D.; Das, A.; Liu, R. S. Chem. Commun. 2010, 46, 4115. (j) Foldi, A. A.; Ludanyi, K.; Benyei, A. C.; Matyus, P. Synlett 2010, 2109. (k) Mori, K.; Sueoka, S.; Akiyama, T. J. Am. Chem. Soc. 2011, 133, 2424. (1) Preciado, S.; Vicente-Garcia, E.; Llabres, S.; Luque, F. J.; Lavilla, R. Angew. Chem., Int. Ed. 2012, 51, 6874.

(14) Orbital symmetry considerations require for 1,3-hydride shifts to occur in antarafacial fashion. This renders these processes essentially geometry-forbidden. See: (a) Woodward, R. B.; Hoffman, R. J. Am. Chem. Soc. 1965, 87, 2511. (b) Berson, J. A. Acc. Chem. Res. 1968, 1, 152.

(15) Product 15 presumably exists as a mixture of diastereoisomers. The $\mathrm{dr}$ could not be determined.

(16) For selected reviews on Baylis-Hillman and aza-Baylis-Hillman reactions, see: (a) Masson, G.; Housseman, C.; Zhu, J. P. Angew. Chem., Int. Ed. 2007, 46, 4614. (b) Shi, Y. L.; Shi, M. Eur. J. Org. Chem. 2007, 2905. (c) Declerck, V.; Martinez, J.; Lamaty, F. Chem. Rev. 2009, 109, 1. (d) Dai, L.-Z.; Shi, M. Chiral Amine Synth. 2010, 397. 
(e) Basavaiah, D.; Reddy, B. S.; Badsara, S. S. Chem. Rev. 2010, 110, 5447.

(17) For examples of aldehydes acting as dipolarophiles in reactions with azomethine ylides, see: (a) Forte, M.; Orsini, F.; Pelizzoni, F. Gazz. Chim. Ital. 1985, 115, 569. (b) Aly, M. F.; Ardill, H.; Grigg, R.; Leongling, S.; Rajviroongit, S.; Surendrakumar, S. Tetrahedron Lett. 1987, 28, 6077. (c) Orsini, F.; Pelizzoni, F.; Forte, M.; Destro, R.; Gariboldi, P. Tetrahedron 1988, 44, 519.

(18) An aqueous workup was performed in each of these experiments to avoid the formation of mixtures of $\mathrm{N}-\mathrm{H}$ and $\mathrm{N}-\mathrm{D}$ aminals (resulting from the expected rapid H/D exchange with solvent) which could complicate the interpretation of spectra.

(19) A control experiment again revealed that deuterium incorporation occurs exclusively during aminal formation. Heating a mixture of nondeuterated $2 \mathrm{e}$ with 2 equiv of THIQ in ETOD under reflux for $16 \mathrm{~h}$ did not lead to any deuterium incorporation.

(20) For an excellent discussion on $P_{\mathrm{H}} / P_{\mathrm{D}}$ vs $K_{\mathrm{H}} / K_{\mathrm{D}}$ values, see: Simmons, E. M.; Hartwig, J. F. Angew. Chem., Int. Ed. 2012, 51, 3066. (21) A $P_{\mathrm{H}} / P_{\mathrm{D}}$ value of 5.2 is calculated based on an expected $\mathrm{D}$ incorporation of 1 to the benzylic position of the dibromoaniline system, consistent with the proposed mechanism. If an alternate mechanism were operative that requires the incorporation of 1 deuterium over all three benzylic $\mathrm{C}-\mathrm{H}$ bonds (benzylic position of the dibromoaniline system + aminal position), the $P_{\mathrm{H}} / P_{\mathrm{D}}$ value would amount to 2.4 .

(22) Zhao, Y.; Truhlar, D. G. Theor. Chem. Acc. 2008, 120, 215.

(23) Marenich, A. V.; Cramer, C. J.; Truhlar, D. G. J. Phys. Chem. B 2009, 113, 6378.

(24) Ribeiro, R. F.; Marenich, A. V.; Cramer, C. J.; Truhlar, D. G. J. Phys. Chem. B 2011, 115, 14556.

(25) Reed, A. E.; Weinstock, R. B.; Weinhold, F. J. Chem. Phys. 1985, 82,735 .

(26) Frisch, M. J. et al. Gaussian 09, Revision C.01, Gaussian, Inc., Wallingford, CT.

(27) (a) Richards, E. L.; Murphy, P. J.; Dinon, F.; Fratucello, S.; Brown, P. M.; Gelbrich, T.; Hursthouse, M. B. Tetrahedron 2001, 57, 7771. (b) Jurberg, I. D.; Peng, B.; Wöstefeld, E.; Wasserloos, M.; Maulide, N. Angew. Chem., Int. Ed. 2012, 51, 1950. (c) Loudon, A. G.; Maccoll, A.; Wong, S. K. J. Chem. Soc. B 1970, 1727. (d) Sueda, T.; Kajishima, D.; Goto, S. J. Org. Chem. 2003, 68, 3307. 